BRUNO DE OLIVEIRA

\title{
ESTUDO DO POTENCIAL VASCULAR DE PRECURSORES DE VASOS CORONÁRIOS EM SÍTIO ADULTO
}

Dissertação apresentada ao Programa de Pós-Graduação em Biologia Celular e Tecidual do Instituto de Ciências Biomédicas da Universidade de São Paulo, para obtenção do Título de Mestre em Ciências. 
BRUNO DE OLIVEIRA

\section{ESTUDO DO POTENCIAL VASCULAR DE PRECURSORES DE VASOS CORONÁRIOS EM SÍTIO ADULTO}

Dissertação apresentada ao Programa de Pós-Graduação em Biologia Celular e Tecidual do Instituto de Ciências Biomédicas da Universidade de São Paulo, para obtenção do Título de Mestre em Ciências.

Área de Concentração: Biologia Celular e Tecidual

Orientador: Prof. Dr. José Xavier Neto 
DADOS DE CATALOGAÇÃO NA PUBLICAÇÃO (CIP)

Serviço de Biblioteca e Informação Biomédica do

Instituto de Ciências Biomédicas da Universidade de São Paulo

reprodução não autorizada pelo autor

Oliveira, Bruno de.

Estudo do potencial vascular de precursores de vasos coronários em sítio adulto / Bruno de Oliveira. -- São Paulo, 2011.

Orientador: José Xavier Neto.

Dissertação (Mestrado) - Universidade de São Paulo. Instituto de Ciências Biomédicas. Departamento de Biologia Celular e do Desenvolvimento. Área de concentração: Biologia Celular e Tecidual. Linha de pesquisa: Biologia do Desenvolvimento.

Versão do título para o inglês: Study of the vascular potential of coronary vessel precursors in adult site

Descritores: 1. Biologia 2. Biologia do desenvolvimento 3.

Embriologia

4. Diferenciação celular 5. 6. I. Xavier Neto, José II. Universidade de São Paulo. Instituto de Ciências Biomédicas. Programa de Pós-

Graduação em Biologia Celular e do Desenvolvimento. III. Título. 
Candidato(a):

Título da Dissertação:

Orientador(a):
Bruno de Oliveira.

Estudo do potencial vascular de precursores de vasos coronários em sítio adulto.

A Comissão Julgadora dos trabalhos de Defesa da Dissertação de Mestrado, em sessão

pública realizada a . $.1 \ldots$ considerou

\section{( ) Aprovado(a) \\ ( ) Reprovado(a)}

Examinador(a): Assinatura:

Nome:

Instituição:

Examinador(a): Assinatura:

Nome:

Instituição:

Presidente: Assinatura:

Nome:

Instituição: 


\section{Certificado}

Certificamos que o protocolo registrado sob $\mathrm{n}^{\circ} \mathbf{1 5 2}$ nas fls. $\mathbf{7 8}$ do livro 02 para uso de animais em experimentação, sob a responsabilidade do $\operatorname{Prof}(a) \operatorname{Dr}(a)$ José Xavier Neto, Coordenador(a) da Linha de pesquisa Estudo do potencial vasculogênico e/ou angiogênico de precursores de vasos coronários em sítio adulto do qual participou(aram) o(s) alunos Bruno de Oliveira, está de acordo com os Principios Éticos de Experimentação Animal adotado pela Sociedade Brasileira de Ciência de Animais de Laboratório (SBCAL) e foi aprovado pela COMISSÃO DE ÉTICA NO USO DE ANIMAIS (CEUA) em 17.11.09, com validade de 3 anos.

São Paulo, 18 de novembro de 2009.

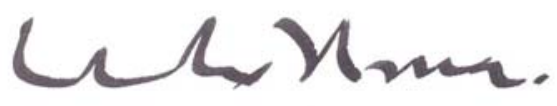

Prof.Dr.WOTHAN TAVARES DE LIMA Coordenador CEEA - ICB/USP

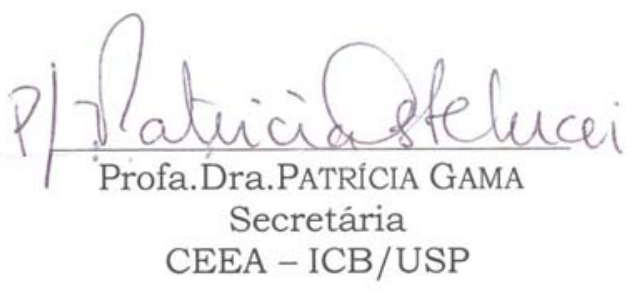


À minha família, pelo apoio fundamental em mais esta jornada. 


\section{AGRADECIMENTOS}

Ao meu orientador Dr. José Xavier Neto. Obrigado pela confiança ao longo destes quase três anos. Agradeço pela orientação, compartilhamento de idéias e troca de experiências.

Ao Dr. José Eduardo Krieger, diretor do Laboratório de Genética e Cardiologia Molecular do Instituto do Coração, pelo apoio.

Ao Dr. Valdo José Dias da Silva, professor da Universidade Federal do Triângulo Mineiro, ex-orientador e um exemplo profissional a ser seguido.

Ao Departamento de Biologia Celular e do Desenvolvimento do Instituto de Ciências Biomédicas da USP e aos seus funcionários, em especial a Celiana Marchiori, pela ajuda prestada.

À CAPES, pelo apoio financeiro.

Aos membros do Laboratório de Genética e Cardiologia Molecular do InCor, em especial a: Renata, Maúde, Silvana, Márcio, Arruda, Sileide e Dona Antônia, pela ajuda diária nas situações mais diversas.

À Ana Lúcia Garippo, pela ajuda em melhorar sempre a técnica de imunofluorescência na obtenção das imagens que fazem parte deste trabalho.

Aos amigos do antigo Grupo de Genética e Desenvolvimento Cardíaco do InCor: Allysson, Ana Azambuja, Débora e Pedro. Obrigado por tornarem o trabalho diário uma atividade prazerosa. Foi ótimo trabalhar com vocês! Agradeço em especial a Ana Azambuja e Allysson pela paciência em me auxiliar enquanto dava os meus primeiros na Biologia do Desenvolvimento.

As grandes amigas Hozana e Sylvia. Agradeço pela amizade, pela ajuda nos experimentos/manuscrito/dissertação, pela troca de experiências, cumplicidade e acima de tudo pela humildade, profissionalismo e respeito que poucas pessoas neste meio conseguem ter. Não poderia deixar de dizer que sem a opinião de vocês essa dissertação não teria amadurecido tanto.

Aos outros companheiros do laboratório. Obrigado pela companhia nos intervalos para o café, idas ao bandeijão, bate papos descontraídos e pelo aprendizado que compartilhamos. 
Aos amigos de fora do laboratório. Obrigado pelo incentivo, pelas conversas sem sentido e momentos de descontração. Agradeço a Thiago Borsari pelo apoio e pela revisão de grande parte do texto e das figuras apresentadas aqui. Obrigado!!!

À minha família, a quem dedico todas as minhas conquistas e em especial a minha avó Severina. Saiba que você é e sempre será minha fonte de inspiração e sempre motivo de orgulho.

Aos meus pais João e Lourdes. Não teria palavras para agradecer tudo o que fizeram e fazem por mim. Obrigado pelo carinho, apoio e incentivo que sempre me deram. Obrigado pela força na realização de mais esta etapa.

A todos aqueles que direta ou indiretamente contribuíram para a realização deste trabalho, muito obrigado!!! 


\section{RESUMO}

Oliveira B. Estudo do potencial vascular de precursores de vasos coronários em sítio adulto. [Dissertação (Mestrado em Biologia Celular e Tecidual)]. São Paulo: Instituto de Ciências Biomédicas da Universidade de São Paulo; 2011.

O Proepicárdio (PE) é uma estrutura transitória que dá origem a todos os componentes dos vasos coronários. Para avaliar o potencial vasculogênico do PE em sítio adulto, nós transplantamos um coração neonatal para o pavilhão auricular de um animal adulto. Duas semanas depois, dois PEs de embriões GFP+ foram transferidos para a superfície deste coração (Grupo A). Em outro grupo, nós transferimos os PEs diretamente para o pavilhão auricular (Grupo B). Para avaliar a incorporação de células GFP derivadas dos PEs, e investigar sua possível diferenciação nós realizamos ensaios de imunofluorescência (IF) para GFP em combinação com outros marcadores: Troponina Cardíaca-1 (cTn-1), Alfa Actina de Músculo Liso (SMaA), PECAM e Óxido Nítrico Sintase Endotelial (eNOS / NOS III). No grupo que recebeu o transplante do coração seguido dos PEs a dupla marcação para GFP e c-Tn1 mostrou extensa incorporação de células GFP+ na periferia do enxerto cardíaco. No mesmo grupo, imunomarcação dupla GFP-SMaA revelou que as células GFP+ foram encontradas entre a camada de células musculares lisas e o lúmen vascular, sugerindo a incorporação das células dos PEs no endotélio vascular. A contribuição endotelial por sua vez foi confirmada nos dois grupos através de IF dupla com GFP e PECAM, marcador precoce de diferenciação endotelial. Imunomarcação dupla para GFP e eNOS, marcador terminal de células endoteliais, foi positiva apenas para o grupo A. Dupla IF PECAM/GFP revelou a presença de agregados celulares semelhantes a ilhotas sanguíneas, compatível com a diferenciação dos precursores coronários antes da diferenciação em endotélio. Portanto, as células do PE diferenciam-se e, provavelmente, participam do processo de neovascularização quando transplantadas para sítios adultos. Estes resultados demonstram que o potencial vasculogênico das células PE é conservado em sítio adulto e que nosso modelo é adequado para estudar os mecanismos envolvidos no desenvolvimento e regeneração vascular.

Palavras-chave: Proepicárdio. Vasculogênese. Angiogênese. Endotélio. 


\begin{abstract}
Oliveira B. Study of the vascular potential of coronary vessel precursors in adult site [Masters Thesis (Cellular and Tissue Biology)]. São Paulo: Instituto de Ciências Biomédicas da Universidade de São Paulo; 2011.
\end{abstract}

The Proepicardium (PE) is a transient extracardiac structure giving rise to all components of the coronary vessels. To evaluate the vasculogenic potential of the PE in an adult site, we transplanted a neonatal heart into the subcutaneous of an adult ear. Later, two PE from GFP-transgenic mice were transferred to the surface of this heart (group A). In another group, we transferred the PEs directly into the ear pinna (group B). To evaluate the incorporation of GFP cells derived from the PE, and to investigate their possible differentiation, we performed immunofluorescence (IF) for GFP in combination with other markers: Cardiac Troponin-1 (cTn-1), Smooth Muscle alpha Actin (SMaA), PECAM and endothelial Nitric Oxide Synthase (eNOS/NOSIII). In the group that received the heart and the PE transplantations, double IF against GFP and cTn-1 showed extensive incorporation of GFP+ cells in the periphery of the grafted heart. In the same group, the double labeling with anti-SMaA revealed that GFP+ cells are found internal to the medial smooth muscle layer and into the lumen, suggesting the incorporation of PE cells in the endothelial layer. The endothelial contribution of PE cells was confirmed in the two groups by double staining with GFP and PECAM, which is an early marker of endothelial and blood differentiation. Double staining with GFP and eNOS, a terminal endothelial marker, was present only in the group that received heart transplantation with PE (group A). Double GFP/PECAM IF revealed colocalization in intraluminal cells, consistent with the blood differentiation that is observed in coronary vessels precursors before overt endothelial differentiation. Therefore PE cells can differentiate and likely participate in the process of neovascularization when transplanted to adult sites. These findings demonstrate that the vasculogenic potential of the PE cells is conserved in an adult site and our model is adequate to study the mechanisms involved in the development and regeneration of vasculature.

Key Words: Proepicardium. Vasculogenesis. Angiogenesis. Endothelium. 


\section{LISTA DE ILUSTRAÇÕES}

Figura 1. Estrutura e movimentos do processo de gastrulação ..........................19

Figura 2. Início do processo de vasculogênese ..............................................20

Figura 3. Processo de formação vascular..........................................................22

Figura 4. Eventos morfogenéticos do desenvolvimento cardíaco ......................27

Figura 5 Formação do epicárdio.......................................................................31

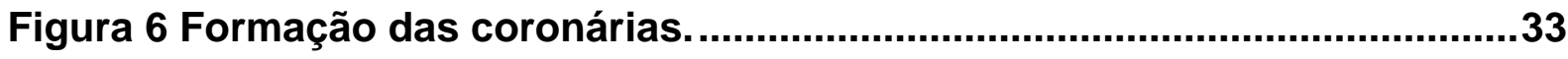

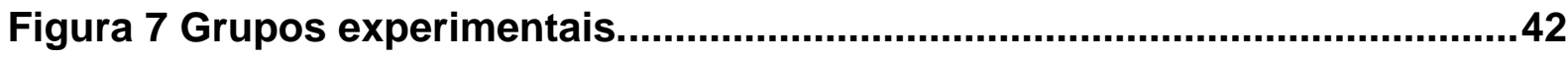

Figura 8. Confecção do túnel entre pele e cartilagem .........................................43

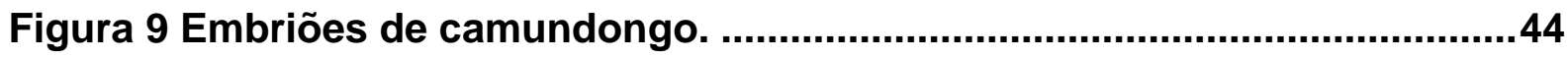

Figura 10 Validação dos experimentos ...........................................................46

Figura 11. Células GFP+ foram encontradas entre a camada de células

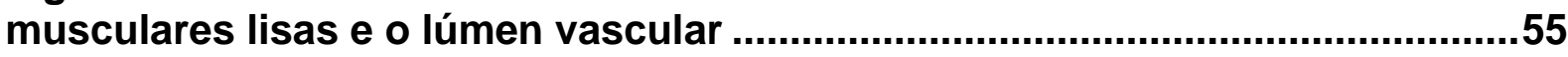

Figura 12 Dupla marcação para GFP e marcadores endoteliais revelou a presença de células derivadas do PE. ..............................................................57

Figura 13. Células GFP+ não expressam troponina cardíaca (cTn-1.................59

Figura 14. Diferenciação do PE em sítio adulto.................................................68 


\section{LISTA DE TABELA}

Tabela 1 - Relação dos anticorpos utilizados. 
1 INTRODUÇÃO E REVISÃO BIBLIOGRÁFICA ...............................................14

1.1 Desenvolvimento vascular ..........................................................................18

1.1.1 Precursores mesodérmicos ...................................................................18

1.1.2 Da formação do plexo vascular primitivo ao estabelecimento do vaso maduro.................................................................................................................21

1.1.3 O papel das células musculares lisas ....................................................23

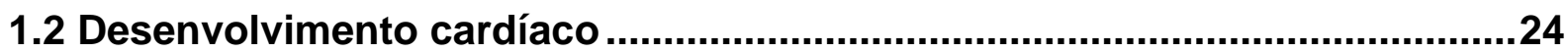

1.2.1 Preparando a zona cardiogênica: o crescente cardíaco e o papel dos morfógenos e fatores de transcrição ............................................................24

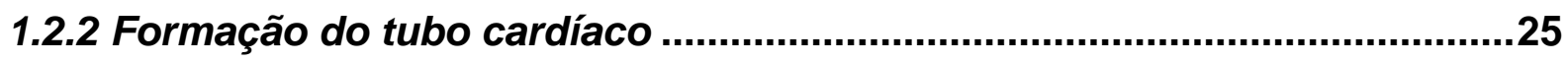

1.2.3 Do coração tubular a um órgão multicameral .........................................26

1.3 Desenvolvimento coronário ...................................................................28

1.3.1 A origem da circulação coronária - o Proepicárdio..................................29

1.3.2 A formação do epicárdio e a transformação epitélio mesênquimal ..........30

1.3.3 O estabelecimento da circulação coronária ............................................32

1.3.4 O papel do epicárdio no desenvolvimento miocárdico ............................34

1.4 Células derivadas do epicárdio e regeneração cardiovascular ....................35

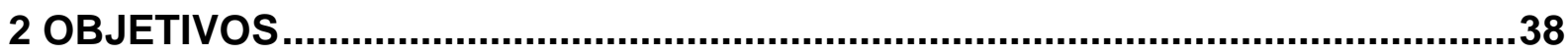

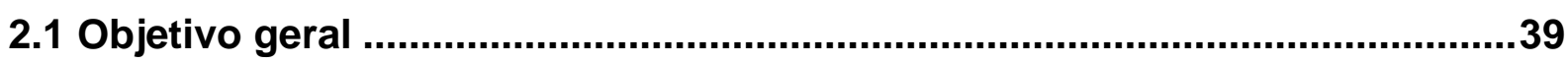

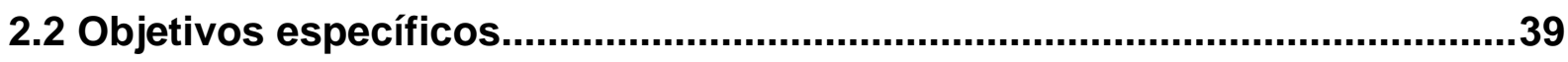

3 MATERIAL E MÉTODOS ................................................................................40

3.1 Grupos experimentais..............................................................................41

3.2 Corações neonatais ...................................................................................42

3.3 Confecção do túnel ...............................................................................42

3.4 Transplante dos corações neonatais ......................................................43

3.5 Embriões de camundongo FVB-GFP .....................................................44

3.6 Dissecção do Proepicárdio ....................................................................45

3.7 Transplante dos PEs ............................................................................ 45

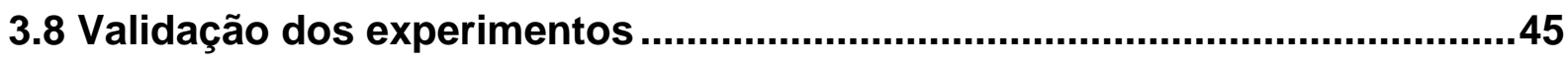

3.9 Processamento histológico.................................................................47

3.10 Imunofluorescência indireta.................................................................47

3.10.1 Aquisição e análise de imagem .............................................................48 
4 RESULTADOS

.50

4.1 Estabelecimento de um modelo de para estudo do potencial de diferenciação de células do PE.....................................................................51

4.2 Células do PE se diferenciam em sítio adulto ...........................................54

4.3 Diferenciação endotelial do PE em sítio adulto.........................................55

4.4 Células do PE não se diferenciam em cardiomiócitos....................................57

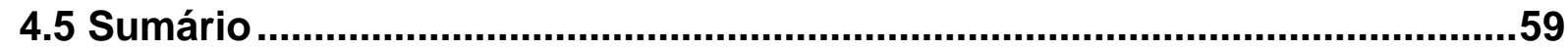

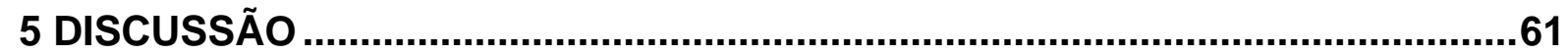

5.1 Vasculogênese e angiogênese no adulto ..................................................63

5.2 Um modelo para diferenciação do PE em sítio adulto .................................64

5.3 Potencial vasculogênico e angiogênico do PE em sítio adulto .....................66

5.4 Precursores endoteliais no reparo vascular ..............................................68

6 CONCLUSÕES .................................................................................................... 71

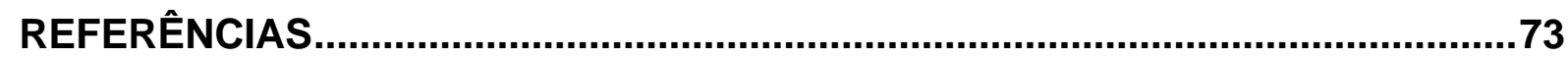


1 INTRODUÇÃO E REVISÃO BIBLIOGRÁFICA 
O sistema cardiovascular é o primeiro a ser estabelecido durante o desenvolvimento embrionário (Manner et al., 2001; Brade et al., 2006). Nas últimas décadas grandes avanços foram conquistados no que diz respeito à compreensão dos mecanismos envolvidos na embriogenia deste sistema, levando a um melhor entendimento dos diferentes mecanismos moleculares e morfogenéticos atuantes em etapas precoces da diferenciação vascular e cardíaca. Além disso, novas descobertas também foram realizadas com relação aos tipos celulares e vias sinalização envolvidas em etapas chave destes processos (Tomanek e Zheng, 2002; Ishii et al., 2007; Lavine et al., 2008; Zhou et al., 2008; Azambuja et al., 2010).

Tendo em vista tais avanços, novas perspectivas de intervenção e prevenção de diversos tipos de doenças cardiovasculares vêm surgindo.

Nos últimos anos abriram-se perspectivas para um uso amplo das células pluripotentes em medicina. Hoje, além dos transplantes de células da medula óssea, diversos modelos terapêuticos têm sido propostos para doenças dos sistemas cardiovascular, endócrino e neuro muscular.

As doenças cardiovasculares apresentam características que as tornam alvos atraentes para a terapia celular (TC), porque em resposta a agressões variadas este sistema apresenta reações estereotipadas destinadas a preservar sua função. Embora eficientes no curto prazo, essas reações regulatórias se tornarão os principais agentes de destruição do órgão ao longo prazo (Orlic et al., 2001). Portanto, a existência de danos semelhantes em agressões heterogêneas fornece uma base racional para o uso de estratégias comuns de preservação da função cardíaca.

Em muitos tipos de doença cardíaca, como em cardiopatias isquêmicas, o objetivo terapêutico é a recuperação da contratilidade do órgão através da ampliação da malha circulatória. Contudo, em casos especiais, como em cardiomiopatia dilatada ou em infartos muito extensos, a reconstituição da contratilidade cardíaca também demanda a adição de miócitos sadios (Orlic et al., 2001; Dimmeler et al., 2005). Para a maioria dessas doenças a ampliação da malha circulatória significa a recuperação de grande parte da função perdida. Assim, novas descobertas que contribuam para o entendimento do processo de diferenciação 
vascular poderiam ser aplicadas para dirigir a diferenciação de células multipotentes ao fenótipo vascular desejado antes da sua inserção no sítio lesado, tornando a TC muito mais segura e eficiente a médio e longo prazos.

Embora a capacidade de diferenciação das células tronco hematopoiéticas em cardiomiócitos tenha sido colocada em dúvida, (Balsam et al., 2004; Murry et al., 2004; Dimmeler et al., 2005) é aparente que todas as modalidades de células-tronco de medula óssea apresentem uma elevada capacidade de diferenciação em células endoteliais, contribuindo de forma marcante para a neo-vascularização pós isquemia ou neo-endotelização pós injúria (Murry et al., 2004; Urbich e Dimmeler, 2004; Dimmeler et al., 2005).

Hoje, diversos tipos de células-tronco, como as embrionárias, germinativas, do cordão umbilical e da medula óssea adulta têm sido cogitadas como fonte para TC (Asahara et al., 1997; Orlic et al., 2001; Dimmeler et al., 2005). Problemas práticos e éticos têm consolidado uma preferência pelas células pluripotentes da medula óssea adulta e graus variados de sucesso têm sido registrados tanto em protocolos clínicos, quanto experimentais, indicando que a TC pode se tornar uma realidade (Dimmeler et al., 2005).

Atualmente, uma nova janela de oportunidade se abriu com a descoberta da indução do fenótipo de células tronco a partir de células terminalmente diferenciadas por transdução viral de alguns genes chave (Takahashi e Yamanaka, 2006). Contudo, ainda há muito que se aprimorar na TC cardíaca, tanto do ponto de vista do conhecimento básico, quanto do ponto de vista operacional a fim de tornar a TC um procedimento de rotina.

Para que o potencial da TC cardíaca possa ser explorado eficazmente é necessário um maior conhecimento da diferenciação dos diversos tipos de células pluripotentes, assim como acesso a sistemas de referência adequados. Para isso, a exploração da embriogenia cardíaca e desenvolvimento dos vasos coronários se tornam alvos interessantes para o melhor entendimento no processo de formação deste sistema, possibilitando identificar desta forma possíveis modelos e vias de diferenciação a serem usados em TC. 
Portanto, com o advento das terapias celulares a busca por alternativas que tornem o transplante autólogo mais seguro e eficiente está cada vez mais presente em nosso cotidiano. Encontrar uma célula que em sítio adulto recupere o fenótipo de seus precursores embrionários e contribua de fato para a reparação de tecidos e órgãos lesados é um grande desafio para os pesquisadores.

O primeiro grupo de precursores da circulação coronária é identificado no proepicárdio (PE), um aglomerado de células derivadas do mesotélio do pericárdio que surge no septo transverso, entre o coração e o broto hepático (Manner, 2000; Brade, 2006). Este grupo de células é formado por diversas vilosidades epiteliais repletas de células multipotentes precursoras de pelo menos quatro tipos celulares: (1) o endotélio coronário, (2) as células musculares lisas coronárias, os (3) fibroblastos coronários e o (4) epicárdio (Manner et al., 2001; Brade et al., 2006). A partir do PE, células precursoras migram para o coração suprajacente e, através de interações adesivas com o miocárdio mediadas por VCAM (molécula de adesão celular vascular-1) e $\alpha 4$ integrina, iniciam um processo de migração e proliferação sobre este órgão (Reese et al., 2002).

O PE, portanto, nos fornece excelentes oportunidades para a identificação dos mecanismos que dirigem uma célula precursora ao destino coronário. Entender melhor a biologia da diferenciação de um grupo de células tão ímpar quanto às do $\mathrm{PE}$, conhecer sua capacidade de diferenciação vascular em sítio adulto e programar sua diferenciação, permitiria o uso dos conhecimentos para o aprimoramento das técnicas de terapia celular já existentes, contribuindo para elucidar as vias de sinalização que dirigem a diferenciação de células multipotentes para os fenótipos encontrados no leito vascular. 


\subsection{Desenvolvimento vascular}

O sistema cardiovascular é o primeiro a se estabelecer durante o desenvolvimento dos vertebrados. O sucesso neste processo permite ao organismo em formação o transporte adequado de nutrientes para diferentes tecidos e descarte de metabólitos; para tanto é necessário o estabelecimento de uma malha vascular que dê suporte a este complexo sistema de transporte. Nesta seção abordaremos o processo de desenvolvimento vascular desde o desenvolvimento de um plexo vascular primitivo, até a formação de um vaso sanguíneo maduro durante o desenvolvimento embrionário.

\subsubsection{Precursores mesodérmicos}

Durante o processo de gastrulação (Figura 1) os três folhetos germinativos, endoderme, ectoderme e mesoderme, são estabelecidos (Risau, 1997). A indução da mesoderme por morfógenos da família dos fatores de crescimento de fibroblastos (FGFs) tem papel essencial na indução da mesoderme lateral e paraxial e na formação dos angioblastos e células hematopoiéticas (Risau e Flamme, 1995). Além dos fatores da família dos FGFs, membros de outra grande família; a dos fatores de crescimento e transformação (TGF- $\beta$ ); foram encontrados induzindo mesoderme, incluindo notocorda e somitos, o que sugere uma atuação sinérgica desses morfógenos durante a formação da mesoderme [revisado por (Risau e Flamme, 1995)]. 


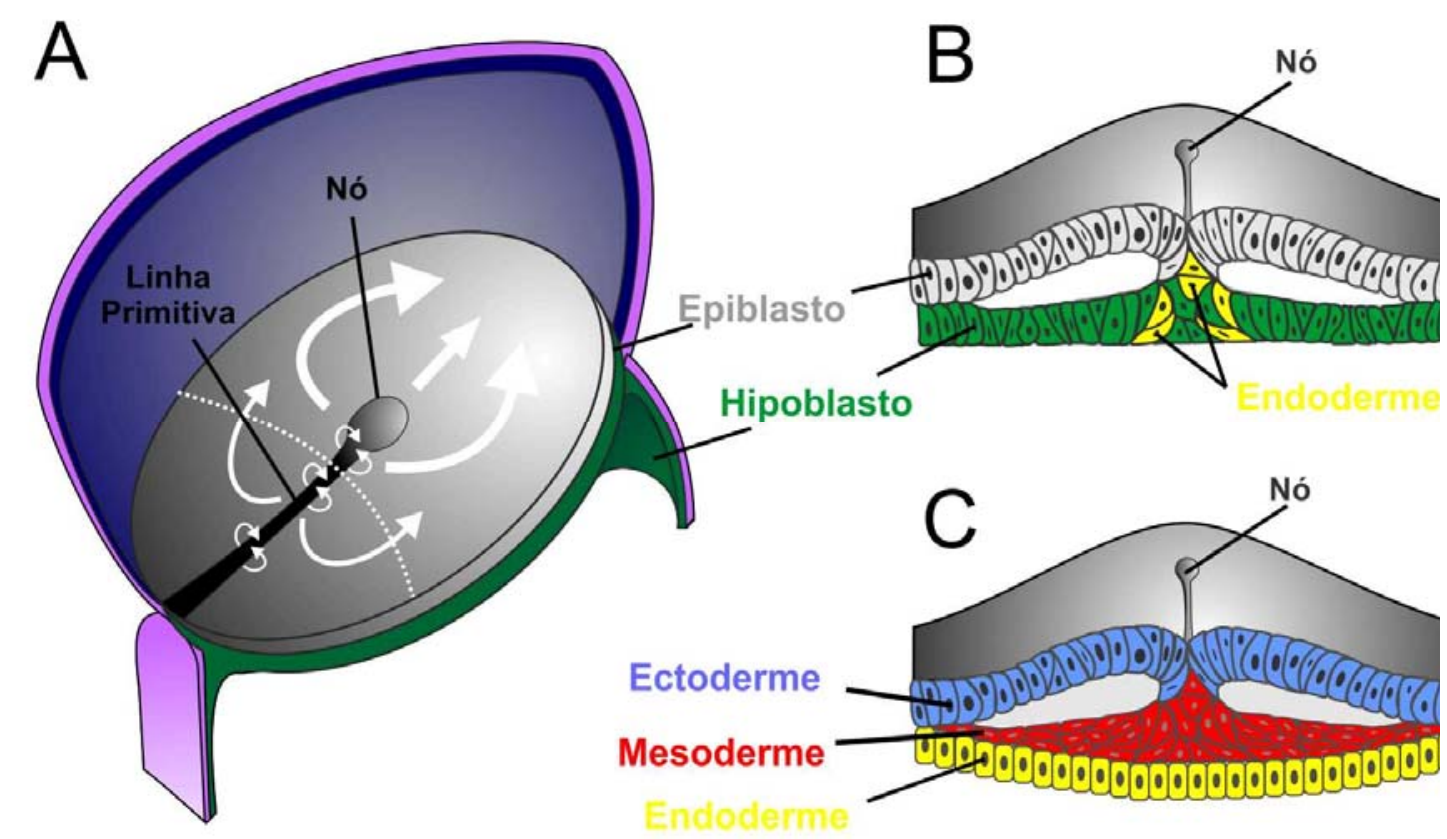

Figura 1. Estrutura e movimentos do processo de gastrulação. (A) Esquema de embrião de humano em estágio de implantação uterina durante a fase de gastrulação, na qual são estabelecidos os três folhetos germinativos (endoderme, mesoderme e ectoderme). Células epiblasticas migram através do nó e sulco primitivo para o espaço entre o epi e hipoblasto (setas brancas). (B e C) Corte transversal do embrião no terço posterior. (B) A entrada de células do epiblasto pelo sulco primitivo e nó aos poucos vai substituindo as células do hipoblasto (que mais tarde farão parte do saco vitelínico), formando a endoderme. (C) Movimento de células do epiblasto; após a formação da endoderme formam agora a camada mesodérmica.

Em mamíferos, os primeiros sinais do desenvolvimento de um plexo vascular primitivo são observados na formação da mesoderme lateral do saco vitelínico. Células hematopoiéticas e endoteliais possuem um precursor comum; o hemangioblasto, induzido na mesoderme pela sinalização de FGF (Risau e Flamme, 1995). No saco vitelínico esses hemangioblastos formam agregados celulares - as ilhotas sanguíneas

Estas ilhotas sanguíneas são aglomerados sólidos de células formados a partir do mesoderma esplâncnico (Figura 2). Na periferia desses agregados celulares encontram se os angioblastos, enquanto o centro das ilhotas é constituído por precursores hematopoiéticos (Risau, 1997; Carmeliet, 2000b). Podemos definir os angioblastos como um tipo celular que expressa alguns marcadores de células endoteliais - marcadores precoces de diferenciação, tais como PECAM (molécula 
de adesão a célula), CD 45, VEGFR-2/ Flk-1 (fator de crescimento endotelial vascular) e vWF (fator de von Willerbrand) - mas que ainda não possuem um lúmen [revisado por (Risau e Flamme, 1995)].

Como mencionado anteriormente, a vasculogênese tem início na mesoderme extra-embrionária do saco vitelínico, onde surgem as primeiras ilhotas sanguíneas. Logo em seguida, surgem os primeiros angioblastos intra-embrionários observados nas laterais do portal intestinal anterior e ventrais ao primeiro par de somitos. Já no estágio de dois pares de somitos ocorre a ligação entre os primórdios vasculares extra e intra-embrionários (Risau e Flamme, 1995).

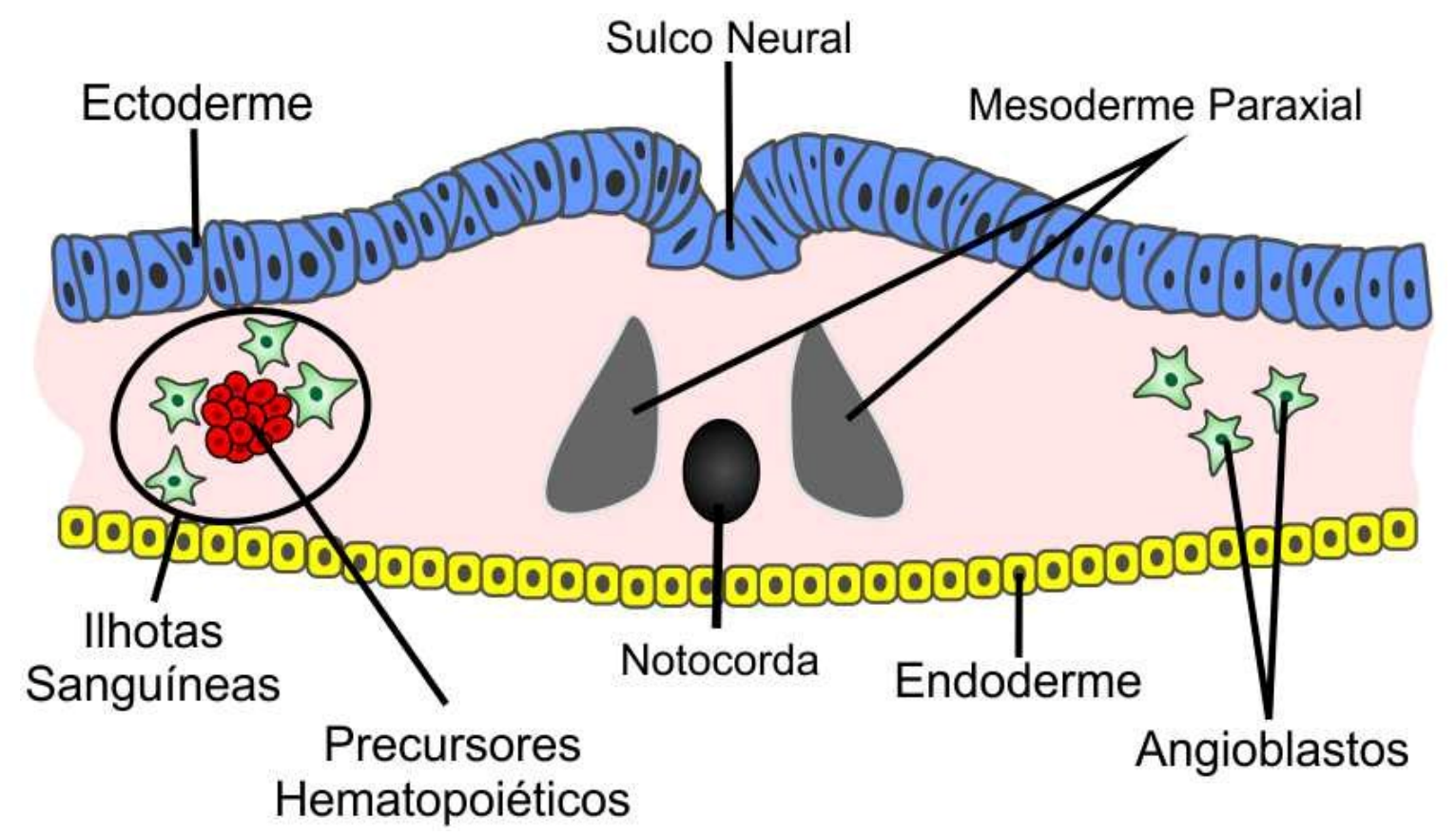

Figura 2. Início do processo de vasculogênese. Corte transversal de embrião de mamífero representando a diferenciação de células mesodérmicas durante o início do processo de vasculogênese. As células mesodérmicas diferenciadas formam as ilhotas sanguíneas que são aglomerados sólidos de células. Na periferia desses agregados celulares encontram se os angioblastos, enquanto o centro das ilhotas é constituído por precursores hematopoiéticos 


\subsubsection{Da formação do plexo vascular primitivo ao estabelecimento do vaso maduro}

Durante o desenvolvimento embrionário de mamíferos os primeiros vasos sanguíneos são formados no meio extra embrionário, já no estágio pós-implantação uterina, a partir dos angioblastos, derivadas das células primordiais, os hemangioblastos (Figura 3A) (Risau e Flamme, 1995; Carmeliet, 2000a).

O primeiro passo na formação dos vasos sanguíneos é a diferenciação dos precursores endoteliais em células endoteliais vasculares, que mais tarde irão constituir a superfície interna de revestimento dos vasos maduros. Este processo é denominado vasculogênese e ocorre através da diferenciação in situ dos hemangioblastos em angioblastos (Figura 3B) [revisado por (Ratajska et al., 2006)].

Dentro do embrião, as células endoteliais se diferenciam a partir da mesoderme como angioblastos isolados, sem a concomitante diferenciação de células hematopoiéticas, exceto por uma pequena região na aorta (grupos paraaórticos) onde ocorre a formação das ilhotas sanguíneas como observado no saco vitelínico. Os angioblastos então migram e fundem-se a outros angioblastos formando uma estrutura semelhante a um labirinto vascular (Figura 3C) (Risau e Flamme, 1995; Ratajska et al., 2006).

Em seguida, esta malha vascular primitiva é expandida e passa por um processo de remodelamento e expansão no qual o tecido endotelial existente se ramifica originando novos vasos num processo denominado angiogênese (Figura 3D) (Risau, 1997). Diferente da vasculogênese, na qual vasos sanguíneos são formados pela agregação in situ de angioblastos e subseqüente diferenciação destes em canais vasculares, o processo de angiogênese compreende o desenvolvimento de vasos a partir de estruturas vasculares preexistentes (Carmeliet, 2000b). Dessa forma, a angiogênese é o mecanismo predominante de formação e/ou neo-formação vascular em fases tardias do desenvolvimento e durante a vida pós natal (Risau e Flamme, 1995).

Alguns fatores são fundamentais para o desenvolvimento vascular. Dentre eles destacam se o fator de crescimento derivado de plaqueta (PDGF) que atua no 
recrutamento de pericitos e células musculares lisas; angiopoitina-1 (Ang-1) e o fator de crescimento e transformação beta-1 (TGF- $\beta 1$ ) na estabilização do vaso nascente e finalmente o fator crucial em todas as etapas do desenvolvimento vascular: o VEGF; morfógeno associado desde a diferenciação das células precursoras endoteliais até fases finais do remodelamento vascular.

A

Migração de Células

Mesodermicas

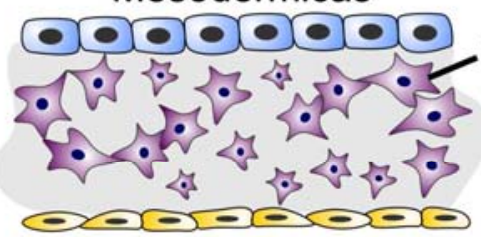

C

Fusão das llhotas e

Diferenciação Endotelial

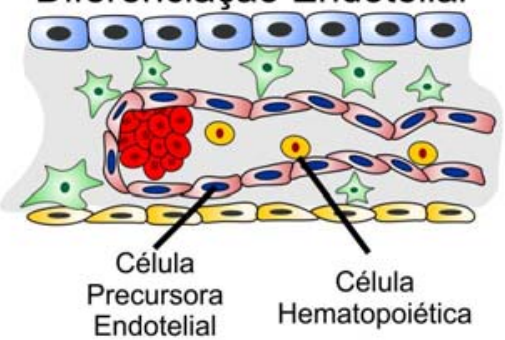

B

Formação das llhotas Sanguíneas

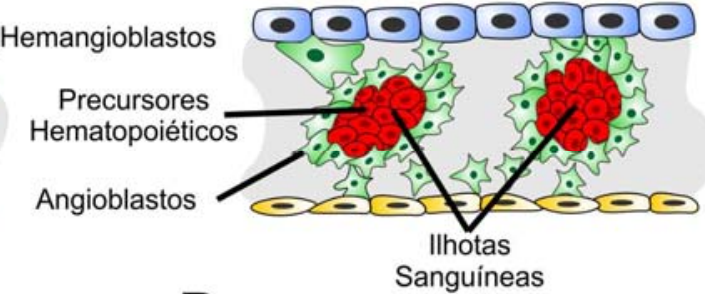

$\mathrm{D}$

Formação do Plexo Capilar

e Vasos Maduros

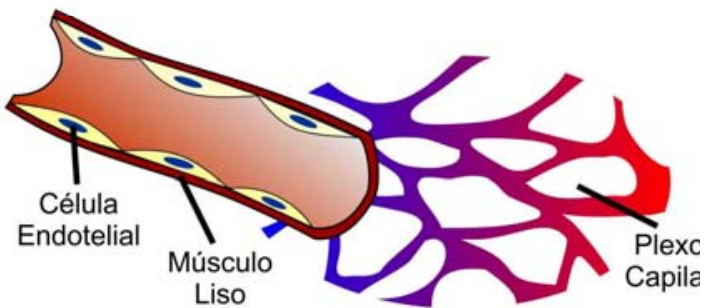

Figura 3. Processo de formação vascular. (A) Induzidos por morfógenos da família dos FGFs as células mesodérmicas se diferenciam dando origem aos hemangioblastos. (B). Esses hemangioblastos formam agregados celulares constituídos internamente por células precursoras hematopoiéticas e revestidos externamente pelos angioblastos (C). A agregação in situ destes angioblastos formam um plexo vascular (primórdios dos vasos sanguíneos). (D) Em seguida, este plexo vascular capilar é expandido e passa por um processo de remodelamento e expansão no qual o tecido endotelial existente se ramifica originando novos vasos num processo denominado angiogênese. Aqui vemos a estrutura simples de um vaso sanguíneo maduro constituído por uma camada de músculo liso e revestido internamente por células endoteliais.

Nos organismos adultos, crescimento e neo-formação vascular ocorrem através dos processos de vasculogênese (desta vez com mobilização de precursores endoteliais da medula óssea) e principalmente angiogênese e arteriogênese (que corresponde ao remodelamento da malha pré-existente) de formas fisiológica e patológica (Risau, 1997; Carmeliet, 2000b). Diversos indutores e inibidores afetam a formação vascular no adulto, entretanto as vias que regulam 
estes processos ainda permanecem pouco compreendidas. Bem estabelecido está o papel de células mediadoras inflamatórias tais como, monócitos/macrófagos, plaquetas e outros leucócitos além dos fatores angiogênicos como VEGF na angiogênese patológica (Risau, 1997; Carmeliet, 2000b; Smart et al., 2009; Kirton e $\mathrm{Xu}, 2010)$.

\subsubsection{O papel das células musculares lisas}

Embora as células endoteliais tenham atraído muita atenção nos últimos anos, elas sozinhas podem iniciar, mas nunca concluir o processo de angiogênese; as células periendoteliais são essenciais para isso. Durante a miogênese vascular células de músculo liso estabilizam o vaso nascente controlando a proliferação e migração de células endoteliais e estimulando a produção de uma matriz extracelular. Nos vasos maduros, as células musculares lisas são importantes porque fornecem proteção ao endotélio contra ruptura, além de permitir o controle hemostático através de alterações no diâmetro do lúmen vascular [revisado por (Carmeliet, 2000b)].

O recrutamento dos precursores de células musculares lisas pelas células endoteliais ainda não foi completamente elucidado. Contudo sabe-se da participação de fatores como o fator de crescimento derivado de plaqueta (PDGF) e VEGF, o primeiro atuando como quimioatrativo e o segundo provocando o acúmulo de células murais. Ang-1 e seu receptor tirosina quinase - Tie-2 participam também deste processo, atuando no crescimento e manutenção dos vasos recém formados, no brotamento e finalmente o remodelamento vascular (Davis et al., 1996; Risau, 1997; Carmeliet, 2000b). 


\subsection{Desenvolvimento cardíaco}

Uma vez estabelecida a malha vascular, tem início a formação do coração; este por sua vez ao completar seu desenvolvimento irá se conectar ao vasos previamente formados. O desenvolvimento cardíaco é um processo complexo controlado por uma cascata de genes reguladores e moléculas sinalizadoras que coordenam diferentes tipos celulares em eventos morfogenéticos contínuos. Portanto, a cardiogênese é um intrincado processo e altamente susceptível a problemas que resultam em defeitos congênitos. Nesta seção iremos abordar aspectos relacionados ao estabelecimento de uma zona cardiogênica, à formação do coração tubular simples, sua integração à circulação embrionária e finalmente os eventos morfogenéticos e mecanismos moleculares que o convertem uma estrutura tubular simples a um órgão multicameral em mamíferos.

\subsubsection{Preparando a zona cardiogênica: o crescente cardíaco e o papel dos morfógenos e fatores de transcrição}

Podemos afirmar que o estabelecimento de uma zona cardiogênica tem início durante a gastrulação. Os progenitores cardíacos movem se através do nó e linha primitiva migrando para as regiões cranial e latero-cranial do embrião, formando desta forma o crescente cardíaco (Figura 4A) (Harvey, 2002; Brade et al., 2006).

O comprometimento de células da linhagem cardíaca é progressivo, espacialmente complexo e altamente dependente dos processos e movimentos celulares, isso porque durante este processo as células em migração vão chegando à região do crescente cardíaco e passam a receber estímulos - ora de indução, ora de repressão - da endoderme, ectoderme adjacente e tecidos extra embrionários (Harvey, 2002). 
É importante ressaltar que já nesses estágios precoces da cardiogênese ocorre a separação dos precursores cardíacos em precursores musculares e precursores endocárdicos através da expressão gênica diferencial (Harvey, 2002).

Os principais morfógenos indutores da mesoderme são: o ácido retinóico (AR), membros da família das proteínas morfogenéticas do ósseas (BMPs) e o fator de crescimento de fibroblasto 8 (Fgf8). Contudo não são apenas estímulos positivos que estabelecem o crescente cardíaco; morfógenos que influenciam negativamente essa região são principalmente moléculas da via de sinalização Wnt e inibidores de BMPs [revisado por (Harvey, 2002)].

Em resposta a estes sinais o crescente cardíaco ativa diversos fatores transcricionais do programa cardíaco dentre eles, Gata4, Nkx2-5, e Tbx5/Tbx20 (Brand, 2003; Hatcher et al., 2004).

\subsubsection{Formação do tubo cardíaco}

Duas ondas de migração celular participam do processo de formação do tubo cardíaco. A primeira onda mobiliza células do mesoderma anterior a partir do nó e da linha primitiva para a porção cefálica do embrião onde está se estabelecendo o crescente cardíaco. A segunda onda de migração celular por sua vez acontece na porção mais ventral do embrião, levando de fato a formação do tubo cardíaco (Figura 4A e B) (Harvey, 2002; Hochgreb et al., 2003).

Nesta fase de formação do tubo cardíaco o embrião está passando por um processo de dobramento lateral, o que possibilita a fusão antero-posterior dos tubos endocárdicos laterais e formação do coração tubular (Figura 4B) (Lie-Venema et al., 2007).

Anterior a este processo de formação dos tubos endocárdicos ocorre a padronização dos precursores cardíacos em relação aos eixos do embrião. Desta vez entra em cena o ácido retinóico $(A R)$ no estabelecimento do eixo anteroposterior (Xavier-Neto et al., 2000). 
Duas fases de sinalização pelo $A R$ no estabelecimento deste eixo são marcadas pela expressão da RALDH2. Esta enzima atua na segunda fase da cadeia de reações de oxidação da vitamina $A$ à $A R$ convertendo o retinaldeído à $A R$ [revisado por (Hochgreb et al., 2003)]. A primeira fase é caracterizada pelo aumento da expressão dessa enzima no mesoderme lateral que contém os precursores sino atriais. A segunda fase é marcada por uma onda caudo rostral da RALDH2 que vai da região mais posterior da área cardiogênica até a porção mais anterior, chegando aos precursores ventriculares e do conotronco (Xavier-Neto et al., 2000; Hochgreb et al., 2003).

Paralelo ao processo de padronização dos eixos embrionários e seguido ao estabelecimento do crescente cardíaco e ondas de migração celular, inicia-se o processo de transformação epitélio mesênquimal do mesoderma da área cardiogênica (Kaufman e Navaratnam, 1981; Harvey, 2002). Este processo, que permite o deslocamento dessas células, leva a formação de um tubo endocárdico interno revestido pelo manto miocárdico externamente (Kaufman e Navaratnam, 1981).

Em fases mais tardias do desenvolvimento cardíaco, a expressão da RALDH2 surge no epicárdio da região sino atrial, participando do espessamento do miocárdio ventricular e no desenvolvimento da circulação coronária (Xavier-Neto et al., 2000; Perez-Pomares et al., 2002b), assunto este que será abordado em maiores detalhes na próxima seção.

\subsubsection{Do coração tubular a um órgão multicameral}

O processo de dobramento lateral inverte a orientação do coração em relação as estruturas neurais e intestino primitivo. Inicialmente o crescente cardíaco era inferior em relação a futura cavidade pericárdica, seguido a este processo os tubos endocárdicos ja fundidos começam a ocupar o espaço pericárdico (Moorman et al., 2003). 
Nesta fase, o tubo cardíaco recém formado ja exibe função contrátil e funciona como uma bomba peristáltica (Buckingham et al., 2005). Neste momento outras alterações importantes começam a ocorrer, células que migram do mesoderme subfaríngeo são adicionadas a porção cranial do tubo cardíaco o que porduz um acentuado alongamento do tubo principal (Buckingham et al., 2005; LieVenema et al., 2007). A principal contribuição desta frente de migração celular para a morfogênese cardíaca é na formação ventrículo direito e trato de saída (Buckingham et al., 2005; Black, 2007).

As células desta última frente de migração caracterizam se pela expressão de alguns marcadores gênicos como: o fator de transcrição LIM homeodomínio - Islet1 (Isl-1), Fgf-10, o fator de transcrição Mef-2c, dentre outros (Brade et al., 2006).

Associado ao processo de alongamento, o tubo cardíaco se inclina para a direita dando início a um processo conhecido como looping (curvatura) cardíaco (Figura 4B e C). Seguido a isso, inicia se o processo de convergência, no qual o seio venoso e o átrio comum "abraçam" os ventrículos (Figura $4 \mathrm{C}$ ). Após a convergência, ocorre o encaixamento em cunha, marcado pelo posicionamento dos coxins do tronco arterial entre as válvulas do canal átrio-ventricular (Figura 4D) (Manner et al., 2001; Buckingham et al., 2005).

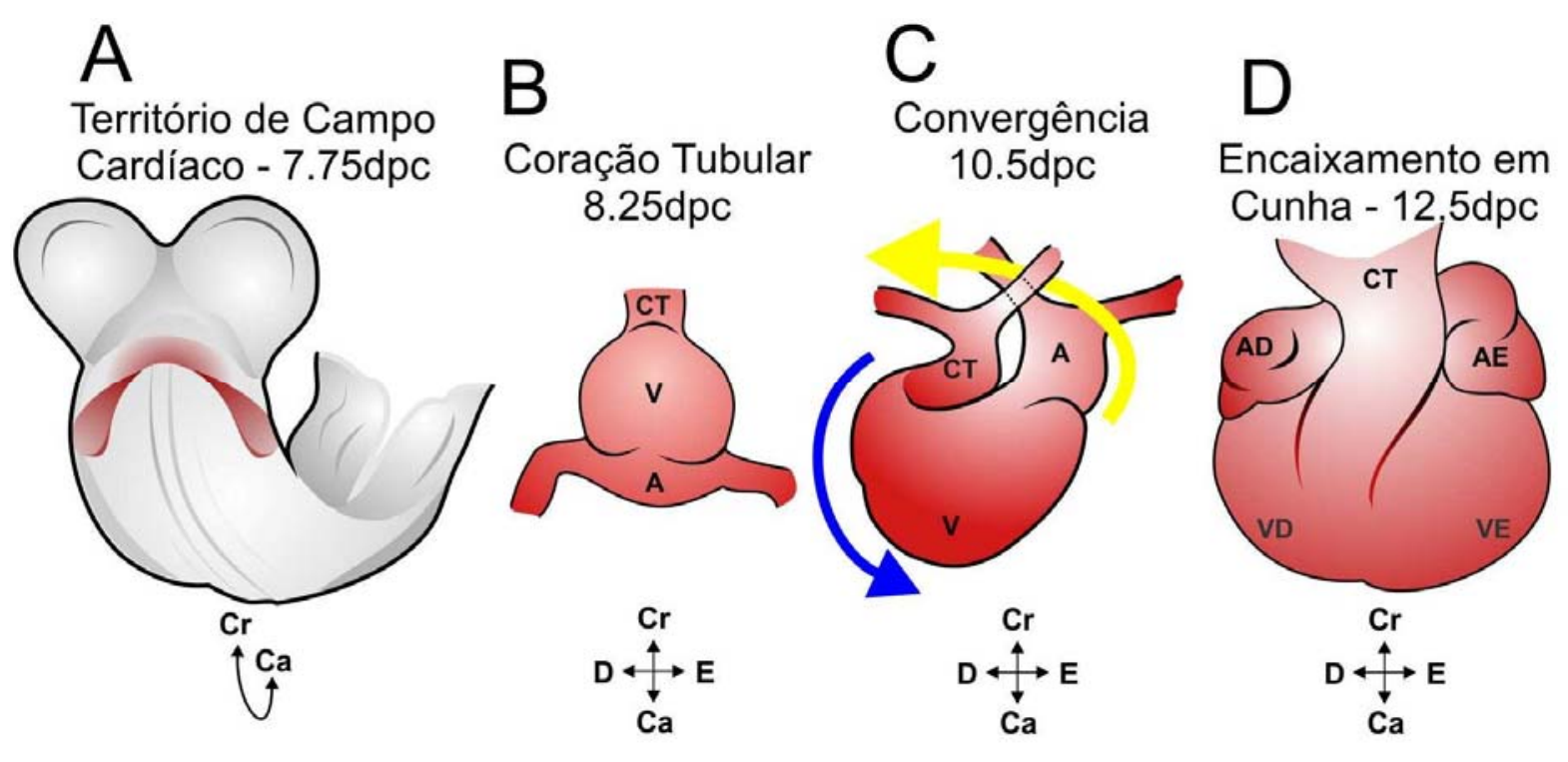

Figura 4. Eventos morfogenéticos do desenvolvimento cardíaco. A) Os progenitores cardíacos são primeiro reconhecidos no território de campo cardíaco, região que se extende cranialmente e lateralmente até próximo aos limites extra embrionários (B) Após fusão dos 
tubos endocárdicos, o crescimento é acompanhado pela contorção do coração tubular onde os precursores ventriculares e conotronco ficam posicionados à direita (seta azul - C). (C) Associado ao processo de alongamento, ocorre aqui a migração da região atrial e seio venoso (influxo) sobre o a região de efluxo, em um movimento de convergência (seta amarela). (D) Após isso temos o processo de encaixamento e remodelamento cardíaco no qual ocorre o posicionamento do tronco cardíaco entre os primórdios das válvulas mitral e tricuspide. dpc, dias pós coito; $C T$, conotronco; $A$, átrio; $V$, ventrículo; $A D$, átrio direito; $A E$, átrio esquerdo; VD, ventrículo direito; VE, ventrículo esquerdo; $\mathrm{Cr}$, cranial; $\mathrm{Ca}$, caudal; $\mathrm{D}$, direita e $\mathrm{E}$, esquerda.

Chegando a este ponto deixamos um tubo peristáltico primitivo para trás e nos encontramos com um órgão mais complexo. A formação de um coração com as quatro câmaras cardíacas é acompanhado pela expressão gênica diferencial em cada parte do coração aliada a outros eventos que levam a um aumento acentuado na complexidade deste órgão. A partir daqui tem início o estabelecimento da circulação coronária, formação de válvulas, septação e surgimento do sistema de condução e finalmente a formação do coração completamente funcional.

\subsection{Desenvolvimento coronário}

Como vimos em seções anteriores, o estabelecimento de um sistema vascular sanguíneo ocorre relativamente cedo durante 0 desenvolvimento embrionário. Durante a cardiogênese os vasos responsáveis pela nutrição do miocárdio - coronárias - surgem em um momento em que a difusão não consegue mais suprir a necessidade deste órgão por nutrientes e oxigênio; fazendo se então necessário o surgimento um sistema de vasos capaz de garantir seu funcionamento.

Antes de começarmos a discutir estrutura e desenvolvimento dos vasos coronários, é importante notar que nem todos os animais possuem este sistema de vasos. Nenhum dos invertebrados possui coronárias e entre os vertebrados apenas mamíferos, aves e répteis (amniotas) tem este sistema completo, com irrigação arterial e retorno venoso. A maioria dos anfíbios não possui vasos coronários e em peixes sua presença é variável [revisado por (Reese et al., 2002)]. 
Nesta seção iremos apresentar a origem da circulação coronária, os aspectos morfogenéticos que levam a formação dos vasos coronários, a formação do epicárdio e finalmente o seu estabelecimento.

\subsubsection{A origem da circulação coronária - o Proepicárdio}

A formação dos vasos coronários é uma etapa crítica para o correto desenvolvimento do coração e envolve diversos processos como vasculogênese, angiogênese e remodelamento vascular, todos já abordados em seções anteriores.

O desenvolvimento coronário tem início com o surgimento de uma estrutura transitória formada por dobras mesoteliais da parede do celoma. $O$ proepicárdio (PE) surge aos 9.5 dias pós coito (dpc) em embriões de camundongo (Figura $5 \mathrm{~A}$ ) e 24 dias em humanos, no septo transverso entre broto hepático e canal atrioventricular (Manner et al., 2001; Tomanek, 2005).

Nas últimas duas décadas diversos trabalhos demonstraram a importância do PE para a correta morfogênese cardíaca. Essa estrutura concentra os precursores das coronárias - endotélio, músculo liso e fibroblastos intersticiais - e do epicárdio, a membrana mais externa do coração (Manner, 1993; Perez-Pomares et al., 1998; Tomanek, 2005).

Contudo não é apenas celular a contribuição do PE para a cardiogênese, diversos experimentos demonstraram que quando o contato dessa estrutura com o miocárdio é impedido, seja por ablação ou mesmo quando este é retirado, não ocorre a formação do epicárdio e leva formação de uma estrutura ventricular hipoplásica. Dessa forma ficou demonstrado um importante papel regulatório no desenvolvimento do miocárdio e morfogênese cardíaca (Manner, 2004). Nas próximas seções explicaremos melhor as vias e sinais epicárdicos no desenvolvimento miocárdico. 


\subsubsection{A formação do epicárdio e a transformação epitélio mesênquimal}

Em mamíferos, o epicárdio é formado a partir de agregados celulares que são liberados do PE em direção a cavidade pericárdica. Em linhas gerais esses agregados são então carregados através do fluido da cavidade pericárdica até a superfície miocárdica onde aderem em diferentes pontos e começam um processo de espalhamento, que termina com o revestimento total deste e formação do epicárdio (Viragh e Challice, 1981; Watanabe et al., 2006).

Em camundongos o número máximo dessas vesículas na cavidade pericárdica ocorre por volta dos 9.5-10 dpc, sendo o período de maior atividade de translocação dessas vesículas observado entre 9-9.5 dpc (Rodgers et al., 2008). A expansão do epicárdio ocorre através da proliferação do PE e de células mesoteliais seguindo um padrão espaço-temporal para o espalhamento dessas células sobre o miocárdio nu (Figura 5B). Inicialmente as células da superfície apical do PE descolam e aderem à parede dorsal do sulco átrio-ventricular. Em seguida, o epicárdio cobre quase que a totalidade da superfície dorsal do ventrículo e se expande para o átrio, região do conotronco e superfície ventral. Ao final do décimo primeiro dia pós coito em camundongos, o coração já está completamente revestido pelo epicárdio (Manner et al., 2001; Ratajska et al., 2006). 

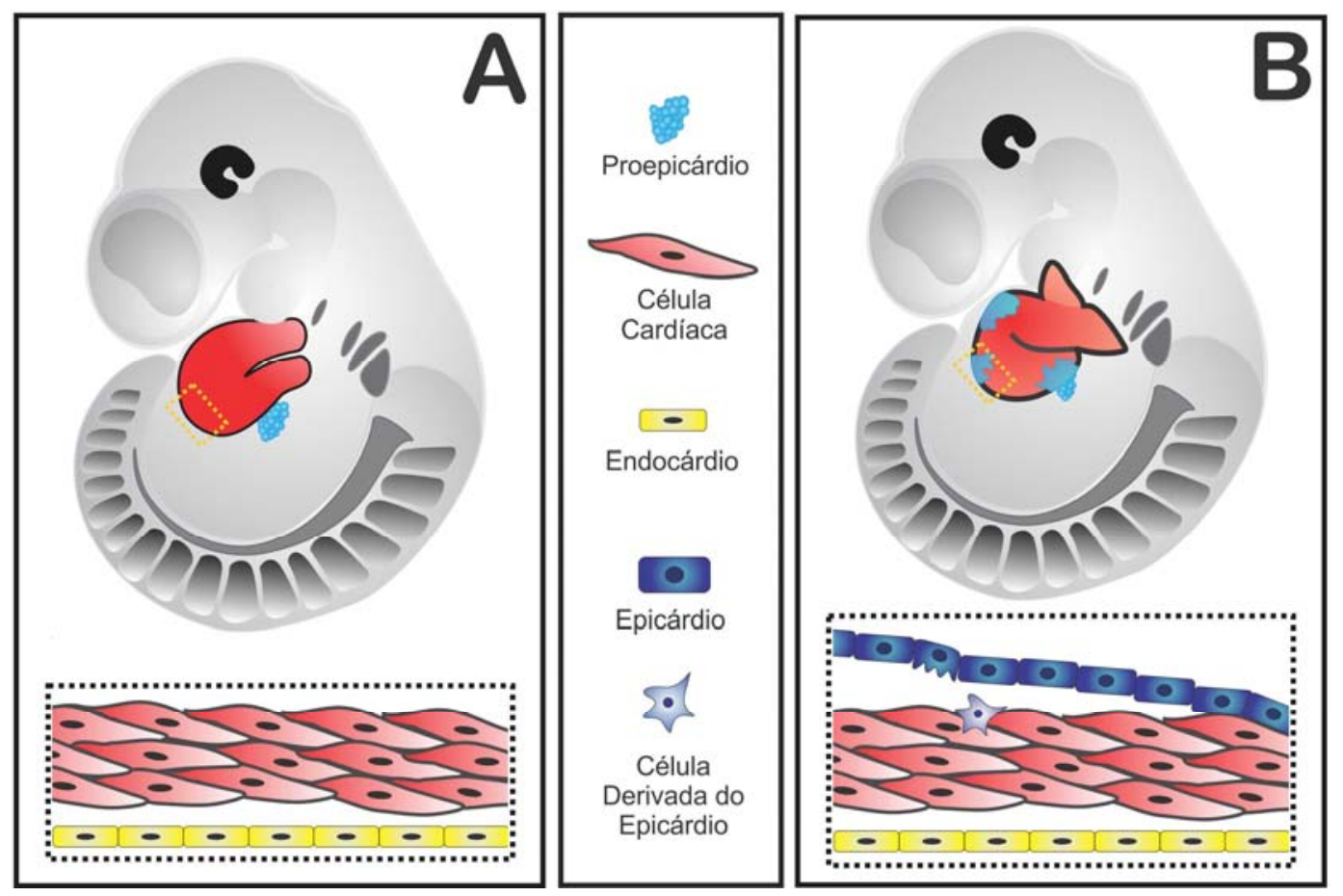

Figura 5. Formação do epicárdio. A vasculogênese coronária inicia se com a formação do proepicárdio (PE) representado em azul. (A) Esquema de um embrião de camundongo aos $9.5 \mathrm{dcp}$, momento em que surge o PE. Notar que ainda nesse estágio o miocárdio representa uma camada muscular fina revestida internamente pelo endocárdio (quadro pontilhado). (B) Após o surgimento do PE, algumas vesículas se destacam e começam a revestir o miocárdio, formando o epicárdio. Notar a presença de células que se destacam da monocamada epicárdica e se transformam em células mesenquimais (azul claro quadro pontilhado).

Durante estágios iniciais da formação do epicárdio esta monocamada de células encontra se aderida a superfície do miocárdio. Posteriormente, devido provavelmente ao acúmulo de fatores de crescimento produzidos pelo miocárdio, cria se um espaço entre miocárdio e epicárdio; o espaço subepicárdico o qual é também constituído por uma sub-população de células epicárdicas (Kalman et al., 1995; Ratajska et al., 2008).

Durante este processo a expressão de fatores de transcrição Slug e Snail por células epicárdicas, associada à produção de fatores de crescimento como TGF- $\beta 1$ e 2 provocam em algumas destas células a perda de suas características epiteliais e sua transformação em células mesenquimais "indiferenciadas" (Figura 5B). A este fenômeno da se o nome de transformação epitélio mesênquimal (TEM) [revisado por (Ratajska et al., 2008). 
Eritrócitos e angioblastos são encontrados neste espaço recém formado constituindo vesículas vasculares primitivas (Tomanek, 2005; Ratajska et al., 2006). Essas vesículas são estruturas muito semelhantes às ilhotas sanguíneas observadas durante o processo de vasculogênese, discutido anteriormente.

A partir daqui, sempre que falarmos das células mesenquimais derivadas do epicárdio nos referiremos a elas como EPDCs (Epicardial Derived Cells).

\subsubsection{O estabelecimento da circulação coronária}

Os vasos coronários se formam a partir de ilhotas sanguíneas, que são agregados de células precursoras endoteliais e hematopoiéticas que durante 0 processo de TEM penetraram no miocárdio [revisado por (Ratajska et al., 2008)]. Em aves e mamíferos, essas estruturas vasculares primitivas podem ser observadas na região do seio venoso e na porção dorsal do sulco átrio-ventricular, região onde tem inicio o processo de formação do epicárdio (Ratajska et al., 2008).

Nesta região algumas EPDCs se fundem e formam tubos endoteliais, posteriormente outras células mesenquimais - também derivadas do epicárdio - se posicionam em torno desses tubos e se diferenciam em células musculares lisas (Figura 6) (Reese et al., 2002).

Como dito anteriormente, para a gênese dos vasos coronários, as EPDCs contribuem fisicamente se diferenciando em endotélio, músculo liso e fibroblastos sob estímulo de diferentes fatores de crescimento, como por exemplo, PDGF e VEGF na diferenciação endotelial ou o fator de crescimento básico de fibroblasto (bFGF) na diferenciação das células musculares lisas (Ratajska et al., 2008). 

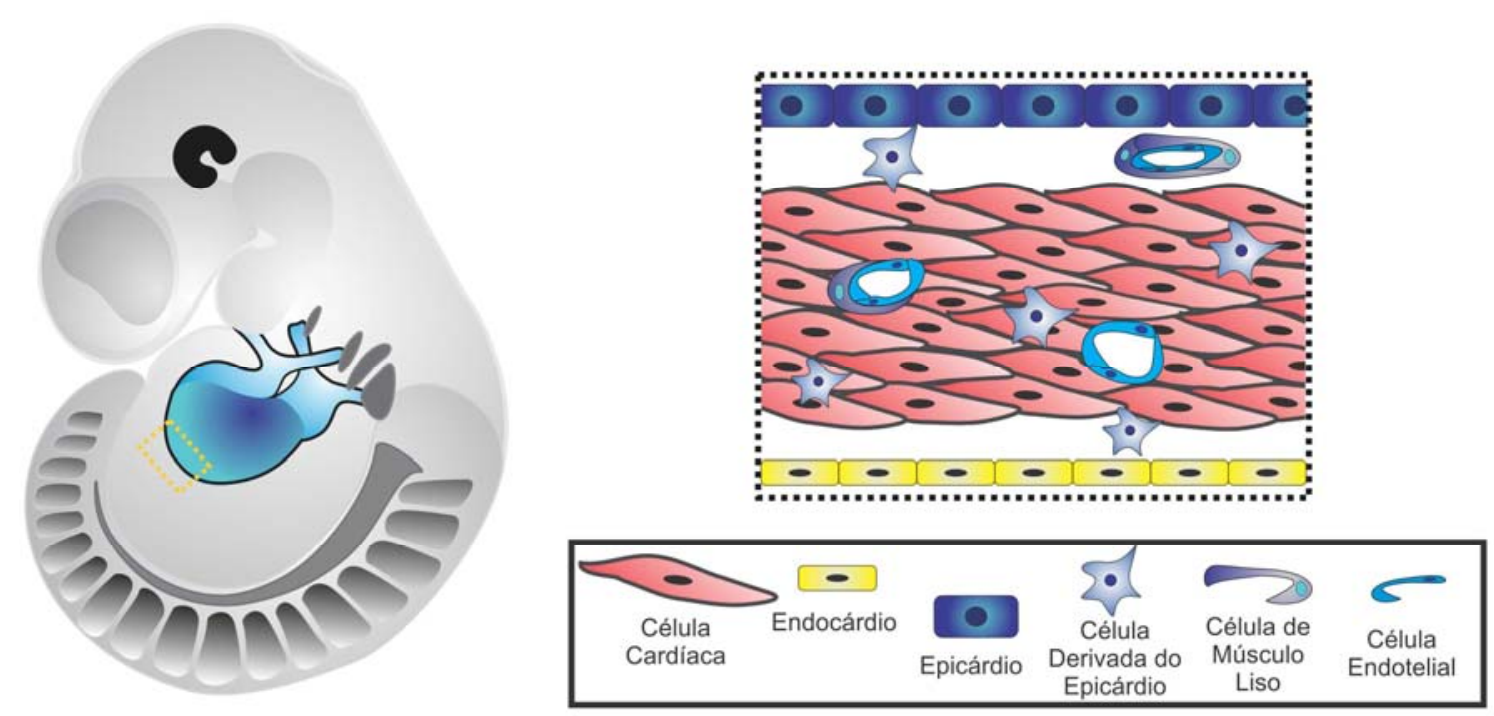

Figura 6. Formação das coronárias. Esquema de um embrião de camundongo aos $11 \mathrm{dpc}$. Neste estágio o coração já está totalmente revestido pelo epicárdico e as células que sofreram TEM (derivadas do epicárdio) diferenciam se nos constituintes dos vasos coronários endotélio, células musculares lisas e fibroblastos (não representados).

Em resumo, o desenvolvimento coronário se dá através do processo de vasculogênese, caracterizado pela diferenciação in situ de precursores vasculares localizados nas ilhotas sanguíneas, fato comprovado por Guadix e colaboradores (2006) quando estes transplantaram o explante do PE de embriões de codorna para diferentes locais, tais como broto dos membros, e broto hepático no embrião de galinha e observaram uma grande incidência de vasos derivados do PE de codorna, demonstrando assim seu alto poder de formação vascular (Guadix et al., 2006).

O desenvolvimento coronário envolve uma série de etapas reguladas por múltiplos mecanismos. Por exemplo, o processo de adesão e migração das células proepicárdicas e epicárdicas é regulado por VCAM (proteína de adesão celular vascular)/integrinas; já a sinalização de GATA-4 nos cardiomiócitos, Slug e Snail garantem a TEM (Crispino et al., 2001; Ratajska et al., 2008). Além disso, durante a TEM e formação dos canais vasculares o miocárdio secreta diversos fatores angiogênicos como FGF-1, 2 e 7, VEGF e angiopoitina-1 (Tomanek et al., 1999; Lavine et al., 2006; Watanabe et al., 2006).

Além da regução miocárdica, o epicárdio atua como centro sinalizador durante o estabelecimento da circulação coronária. As vias de sinalização de Hedgehog (Hh), VEGF, Ang-2 são essenciais para o desenvolvimento deste sistema 
(Lavine et al., 2008). A sinalização de FGF pelo miocárdio, associada a expressão dos receptores de FGF (Fgfr-1 e 2) nas células epicárdicas provoca uma onda de sinalização por $\mathrm{Hh}$ desde o sulco átrio ventricular até o ápice dos ventículos induzindo a expreção de VEGF-A, B e C e Ang-2 pelas células miocárdicas, resultando na formação do plexo vascular coronário (Lavine et al., 2006).

Ao final deste processo ocorre a conexão do plexo coronário ao tronco da aorta e endocárdio atrial, conectando a circulação coronária à circulação embrionária pré-existente. (Reese et al., 2002; Ratajska et al., 2008).

\subsubsection{O papel do epicárdio no desenvolvimento miocárdico}

Como citado anteriormente, a formação do epicárdio é necessária para o completo desenvolvimento do miocárdio e para a correta vascularização da parede cardíaca. Durante o desenvolvimento cardíaco, o epicárdio tem uma contribuição essencial na secreção de fatores que contribuem com: (1) a formação dos vasos coronários, (2) a proliferação dos cardiomiócitos, (3) o desenvolvimento ventricular, (4) no processo de compactação do miocárdio (Li et al., 2009; Sucov et al., 2009; Brade et al., 2011) e ainda (5) com a diferenciação de progeniores epicárdicos em cardiomiócitos (Zhou et al., 2008).

As células epicárdicas contribuem não só fisicamente para a cardiogênese, mas também proporcionam sinais tróficos que levam à proliferação do miocárdio via sinalização por AR, eritropoitina (Epo), TGF $\beta$, Hh, Fgfs, dentre outras vias (Lavine et al., 2006; Li et al., 2009; Sucov et al., 2009; Brade et al., 2011). O papel de Hh e dos Fgfs foram discutimos anteriormente durante o estabelecimento da circulação coronária (Lavine et al., 2008), a partir de agora vamos apresentar o papel das outras vias para o final do desenvolvimento miocárdico.

O papel do AR para a morfogênese cardíaca foi apresentado anteriormente quando tratamos do desenvolvimento cardíaco, sendo este fundamental na indução da mesoderme (Xavier-Neto et al., 2000; Hochgreb et al., 2003) e para o 
recrutamento de células do mesoderma esplâncnico na formação do trato de saída (Li et al., 2009). Durante e após a formação do epicárdio este morfógeno atua em conjunto com outras vias em processo como diferenciação de células do trato de saída, proliferação e compactação do miocárdio ventricular e septação do trato de saída (Li et al., 2009; Lin et al., 2010; Brade et al., 2011).

$\mathrm{Li}$ et al. (2009) e Brade et al. (2011) utilizando embriões de camundongo knockouts para a raldh2 (raldh2-/-) e para receptores de AR (Rxr-/-) demonstraram a influência da sinalização pelo AR nos processo apresentados anteriormente. No caso da expansão e compactação miocárdica ventricular o $A R$ não atua diretamente, mas utiliza como alvo o gene da Epo responsável pela por induzir, via sinalização por IGF-2 (insulin growth factor 2) secretado pelo epicárdio, a expansão e compactação do miocárdio ventricular (Li et al., 2009; Brade et al., 2011). Já os processos de diferenciação do trato de saída e septação deste ocorrem sob influencia da via AR - TGF- $\beta$ (Li et al., 2009).

Além do papel regulatório do epicárdio nos processos apresentados acima, não podemos deixar de mencionar a importância das EPDCs na diferenciação de cardiomiócitos em células especializadas na condução do impulso nervoso - as fibras de Purkinje (Gittenberger-de Groot et al., 2003) além da formação das válvulas cardíacas, esqueleto fibroso do coração ou diferenciação em fibroblastos intersticiais, responsáveis pela síntese de matriz extracelular (Winter e Gittenbergerde Groot, 2007).

\subsection{Células derivadas do epicárdio e regeneração cardiovascular}

As doenças vasculares, em especial problemas nas artérias coronárias são a principal causa de morte atualmente e a manutenção da integridade funcional da camada endotelial vascular é fundamental para evitar o desenvolvimento destes processos (Kirton e Xu, 2010).

Uma série de trabalhos com PE e EPDCs tem enfocado suas análises nos mecanismos que controlam a conversão de células epicárdicas em células 
mesoteliais, via TEM e a consequente geração das EPDCs (Wada et al., 2003; van Tuyn et al., 2007); enquanto outros buscam por diferentes formas de dirigir a diferenciação do PE e das EPDCs (Manner, 1999; Perez-Pomares et al., 2002b; Azambuja et al., 2010). Elucidar as vias que controlam a diferenciação epicárdica e que alterem os processos de diferenciação destas células ajudaria não somente no entendimento da cardiogênese normal, mas também forneceria uma nova visão sobre a etiologia de algumas doenças cardíacas congênitas.

Nos últimos anos uma quantidade considerável de informações sobre o PE e seus derivados tem sido acumulada. Sabe se que após a formação do epicárdio, TEM e diferenciação em vários tipos celulares, algumas EPDCs permanecem em estado de latência, indiferenciadas, funcionando como células-tronco cardíacas (Wessels e Perez-Pomares, 2004).

As EPDCs são células multipotentes e verdadeiras células-tronco cardíacas tendo a capacidade de se diferenciar em diversos tipos celulares, incluindo fibroblastos cardíacos, células musculares lisas e células endoteliais (Manner, 1999; Perez-Pomares et al., 2002b; Wada et al., 2003; Wessels e Perez-Pomares, 2004; van Tuyn et al., 2007).

Pouco se sabe sobre a regulação espaço-temporal das EPDCs, contudo na última década alguns candidatos tem sido levantados como possíveis reguladores da sua diferenciação. Pérez-Pomares et al. em 2002 associaram que uma redução na expressão de WT-1 (Wilms Tumor Protein-1) é necessária para a diferenciação das EPDCs em endotélio vascular e músculo liso (Perez-Pomares et al., 2002b). Por outro lado, O ácido retinóico, através da sua enzima conversora a RALDH2, atua mantendo as células do PE em seu estado indiferenciado (Azambuja et al., 2010). Provavelmente essa interação entre WT-1 e AR tem um papel fundamental na manutenção destas células em um estado indiferenciado.

Portanto, a compreensão dos mecanismos embrionários nos processos de vasculogênese e angiogênese se torna inestimável no desenvolvimento de novas estratégias para terapias de regeneração cardiovascular (Smart et al., 2009). Com base nisso, neste trabalho buscamos estabelecer um modelo de diferenciação vascular in vivo dos precursores dos vasos coronários, concentrados no PE, em um 
sítio adulto, utilizando um modelo murino, visando, desta forma, entender melhor a biologia de diferenciação do PE. 
2 OBJETIVOS 


\subsection{Objetivo geral}

Estabelecer modelos de neovascularização utilizando explantes de células do proepicárdio (PE) em sítio adulto com e sem a presença de coração.

\subsection{Objetivos específicos}

a) Padronizar a transferência de células do PE para sítio adulto.

b) Padronizar as condições de transferência de células do PE para corações neonatos em posição ectópica e sítio adulto.

c) Caracterizar a diferenciação das células do PE quando transplantadas para sítio adulto com e sem a presença de tecido cardíaco. 
3 MATERIAL E MÉTODOS 
Foram utilizados camundongos das seguintes linhagens para 0 desenvolvimento do trabalho: FVB-WT e FVB-GFP (transgênico expressando ubiquamente a proteína fluorescente verde). As linhagens de animais transgênicos foram desenvolvidas no Instituto do Coração sob supervisão do Dr. José Xavier Neto.

Todos os animais receberam cuidados em conformidade com os Principles of Laboratory Animal Care, formulado pela Sociedade Nacional de Pesquisa Médica e o Guide for the care and use of laboratoy animals preparado pelo Instituto Nacional de Saúde (NIH, sigla em inglês). O projeto de pesquisa foi aprovado pela Comissão de Ética no Uso de Animais do Instituto de Ciências Biomédicas da Universidade de São Paulo (CEUA-ICB-USP).

\subsection{Grupos experimentais}

No presente trabalho utilizamos um modelo de transplante do PE para um coração ectópico enxertado na região subcutânea do pavilhão auricular de camundongos receptores, descrito anteriormente (Fulmer et al., 1963; Fey et al 1998). Estes corações são capazes de se integrar à rede vascular local, o que It permite continuar sua atividade contrátil e mostrar extensa sobrevida, compatível com a realização dos experimentos que programamos.

Nossos grupos experimentais foram constituídos da seguinte forma: Grupo (A) no qual foi transplantado um coração neonatal de animal FVB-WT para o pavilhão auricular de um animal receptor também FVB-WT e após duas semanas foi realizada a transferência de dois PEs de embriões 9.5dpc FVB-GFP sobre a região ventricular do coração transplantado (Figura 7A); e Grupo (B) no qual transplantamos apenas os dois PEs para o pavilhão auricular de camundongos receptores FVB-WT (Figura 7B). Fizemos uso também um grupo controle no qual apenas o túnel entre pele e cartilagem foi confeccionado. 

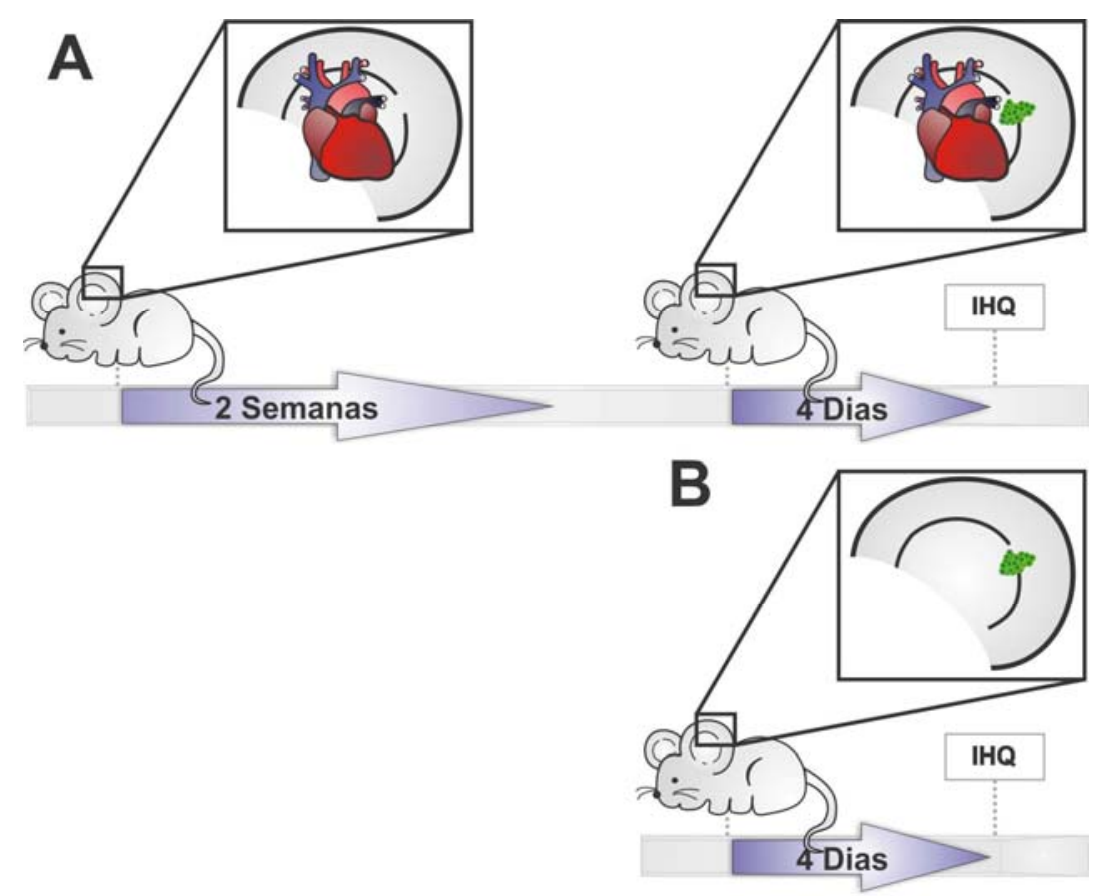

Figura 7. Grupos experimentais. (A) Grupo que recebeu o transplante do coração neonatal. Após duas semanas a pele sob o enxerto foi seccionada e o explante dos PEs de embriões de FVB-GFP transferidos para o miocárdio. (B) Grupo que recebeu apenas o transplante dos PEs de embriões FVB-GFP. Em ambos os grupos, quatro dias após a transferência do PE para o pavilhão auricular os animais foram sacrificados e as orelhas coletadas, processadas e incluídas para ensaios de imunohistoquímica (IHQ).

\subsection{Corações neonatais}

Os corações neonatais foram obtidos de camundongos recém nascidos com no máximo 24 horas de vida (Fey et al., 1998). Os camundongos neonatos foram anestesiados em câmara de $\mathrm{CO}_{2}$ e em seguida decapitados, só então o procedimento para extração do órgão foi realizado. O coração foi lavado em solução de PBS (Salina Tamponada com Fosfato/Phosphate Buffer Solution) estéril

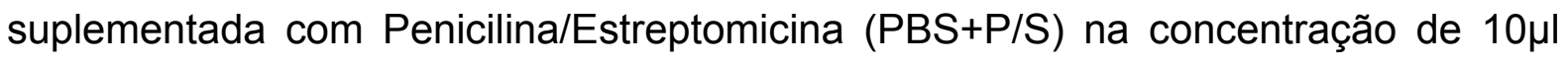
$\mathrm{P} / \mathrm{S} / \mathrm{ml}$ PBS.

\subsection{Confecção do túnel}


Para a realização dos transplantes foi confeccionado um túnel entre pele e cartilagem da orelha (Figura 8) com o auxílio de uma agulha hipodérmica (Intracath) 14G, segundo técnica descrita por Fulmer e colaboradores em 1963 (Fulmer et al., 1963). Os animais foram anestesiados com uma mistura de anestésico e relaxante muscular (Ketamina/Xilasina) na concentração de $2 \mathrm{ml} / \mathrm{kg}$, de acordo com o peso do animal. Com os animais já anestesiados foi realizada a tricotomia da região auricular, assepsia com etanol $70 \%$ e finalmente a confecção do túnel para inserção do coração e/ou dos PEs.

\subsection{Transplante dos corações neonatais}

Após explantados e lavados os corações foram inseridos na orelha de camundongos receptores através do túnel confeccionado previamente entre pele e cartilagem da orelha. Depois da transferência do órgão a abertura foi suturada e os animas foram acondicionados individualmente em gaiolas plásticas com livre acesso à água e comida.

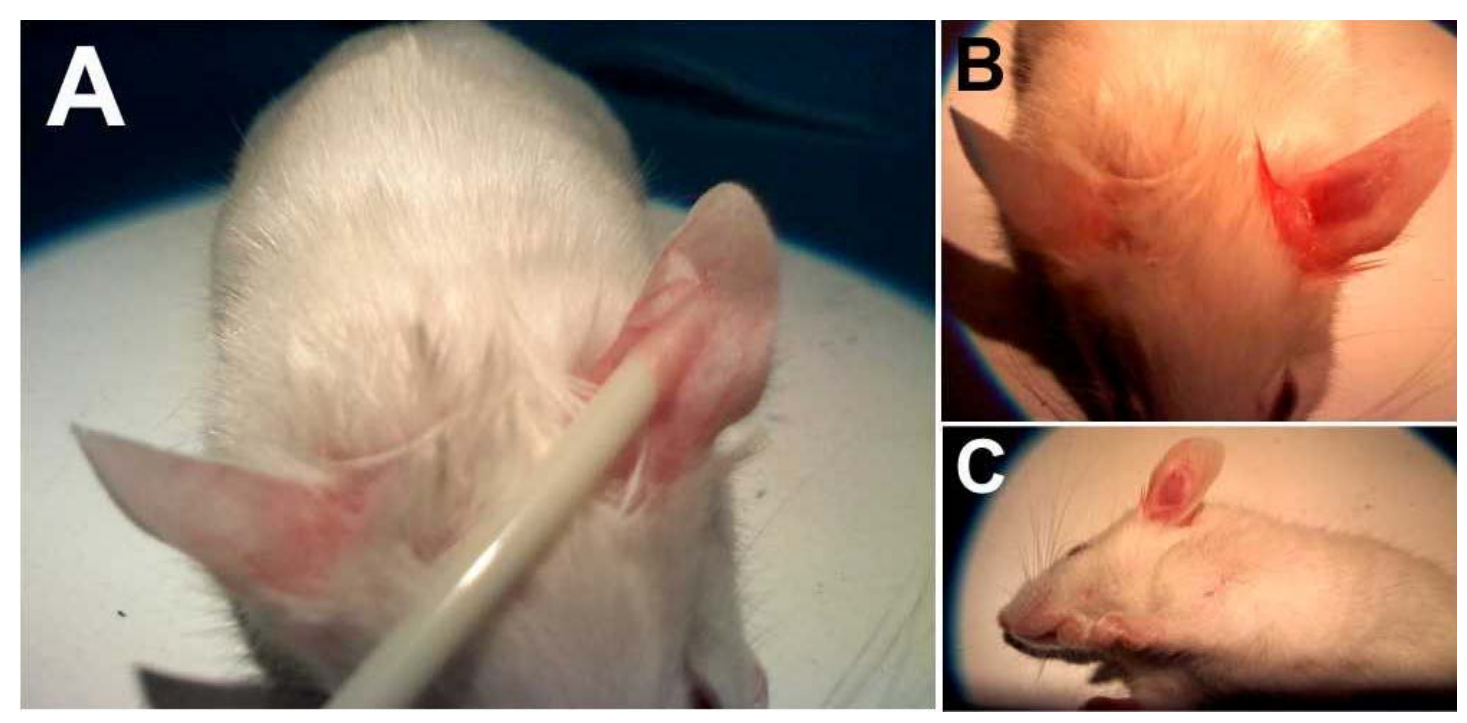

Figura 8. Confecção do túnel entre pele e cartilagem. Para o transplante do coração neonatal no pavilhão auricular, um túnel entre pele e cartilagem do foi confeccionado com auxílio de 
uma agulha hipodérmica. (A) Túnel entre a pele e cartilagem da orelha. Vista dorsal (B) e lateral $(\mathrm{C})$ após transplante do coração.

\subsection{Embriões de camundongo FVB-GFP}

Para a obtenção dos PEs de embriões de camundongos a gestação das fêmeas foi estagiada através da observação da presença da rolha (plug) vaginal na manhã seguinte ao acasalamento, sendo este considerado o dia 0,5 do desenvolvimento. Para os experimentos deste trabalho os embriões de camundongo foram coletados após $9.5 \mathrm{dpc}$.

Embriões de camundongo foram obtidos por histerectomia. Os cornos uterinos foram coletados em PBS+P/S cuidadosamente dissecados em estereomicroscópio com auxílio de pinças de dissecção e tesouras finas e os embriões removidos dos anexos embrionários. Os embriões então foram lavados em solução de PBS + P/S e fenotipados em estereomicroscópio com fluorescência acoplada utilizando filtro para GFP $(515 \mathrm{~nm}-565 \mathrm{~nm})$ (Figura 9).

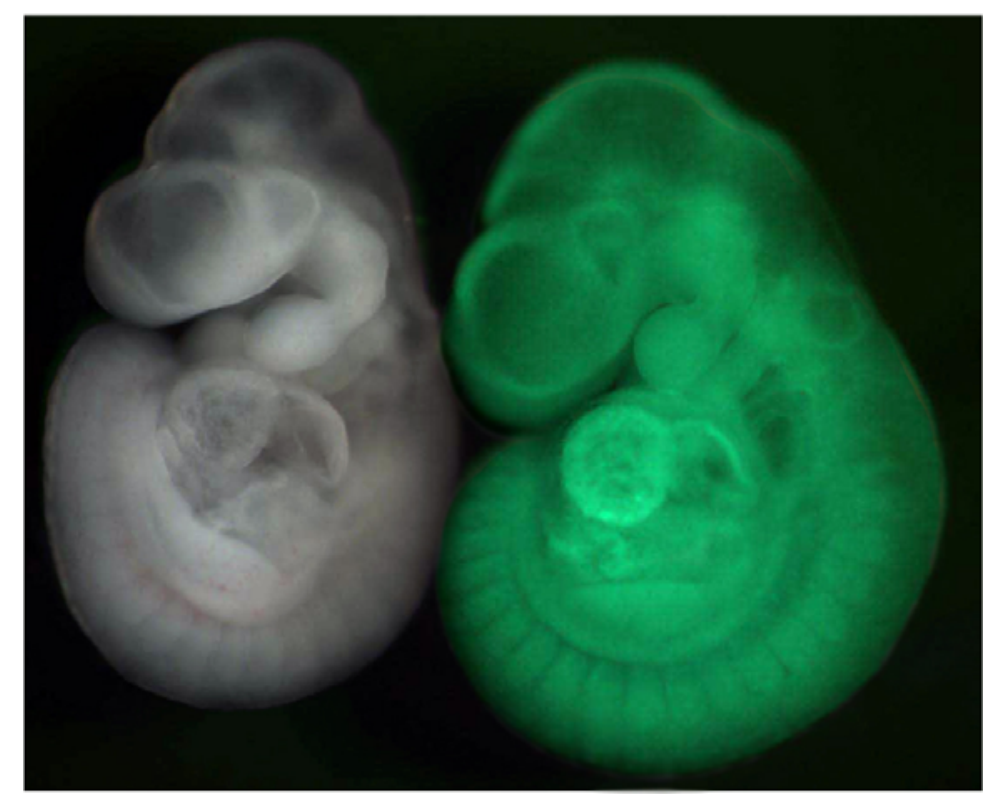

Figura 9. Embriões de camundongo. Fotografia tirada em esteromicroscópio de embriões de camundongo com $9.5 \mathrm{dpc}$. No lado esquerdo da foto observamos um embrião da linhagem 
FVB-WT fotografado em luz branca, enquanto no lado direito podemos ver um embrião transgênico FVB-GFP fotografado em fluorescência sob filtro para GFP.

\subsection{Dissecção do Proepicárdio}

A coleta dos PEs foi realizada após remoção do pericárdio e pinçamento do PE dissecado do septo transverso de embriões 9.5dpc em esteromicroscópio com auxílio de pinças finas. $O$ explante foi aspirado utilizando capilar de vidro conectado à tubo de aspiração e mantido em meio de cultura DMEN (Dulbecco's Modified Eagle's Medium) suplementado com $15 \%$ de soro fetal bovino (SFB) (Azambuja et al., 2010) sobre placa aquecida a $37^{\circ} \mathrm{C}$ até a transferência para o pavilhão auricular.

\subsection{Transplante dos PEs}

Para os animais do grupo $(A)$, que receberam o enxerto do coração neonatal, 14 dias após o transplante, a pele do pavilhão auricular foi seccionada e afastada para viabilizar o acesso ao coração. O tecido epicárdico do coração ectópico foi removido localmente por fricção com uma agulha de insulina e no miocárdio exposto foi recoberto com dois explantes do PE removidos de embriões FVB-GFP. Após alguns minutos necessários à adesão dos $\mathrm{PEs}$, a pele do pavilhão foi suturada e os animais reconduzidos às suas gaiolas. Para os animais do grupo (B) dois PEs coletados de embriões transgênicos FVB-GFP foram diretamente transferidos para o espaço, entre pele e cartilagem da região auricular, descrito anteriormente.

\subsection{Validação dos experimentos}


Para ambos os grupos, quatro dias após o transplante dos explantes dos PEs os animais foram sacrificados em câmara de $\mathrm{CO}_{2}$. As orelhas foram cortadas $\mathrm{e}$ examinadas em estereomicroscópio com fluorescência. Nossos experimentos foram considerados válidos quando alguma fluorescência foi observada sob filtro para GFP (considerada como derivada dos PEs de embriões transgênicos) (Figura 10). 0 material positivo seguiu, então para o processamento histológico.
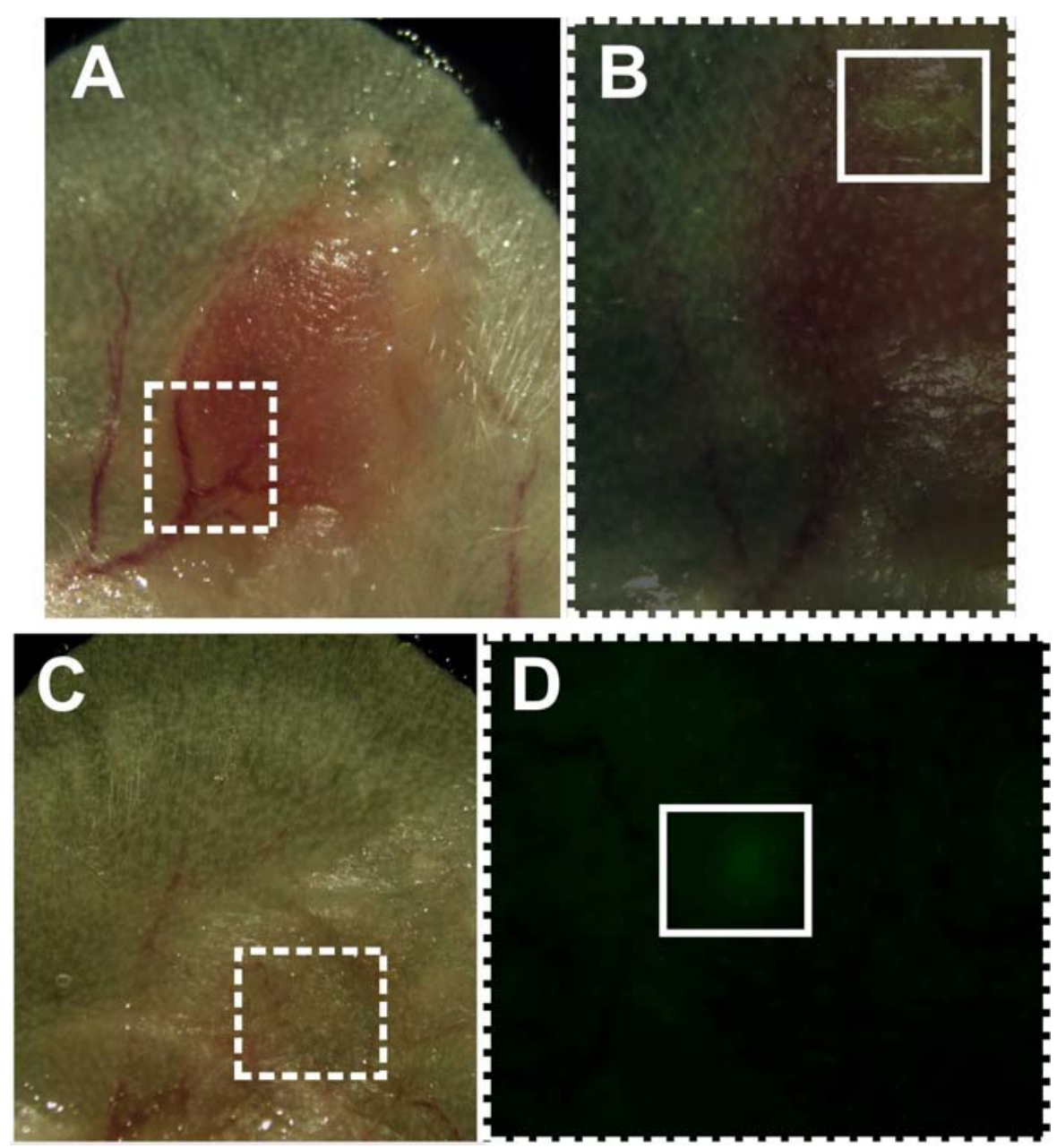

Figura 10. Validação dos experimentos. Quatro dias após o transplante do PE os animais foram sacrificados, as orelhas coletadas e observadas em esteromicroscópio com fluorescência. (A e B) Transplante do grupo "A". (D e E) Transplante do grupo "B". Os experimentos foram considerados válidos, e assim seguiam para o processamento histológico, quando alguma fluorescência foi observada em regiões vicinais à área de transplante do PE extraído de embriões FVB-GFP+. (B e D) Ampliação das áreas destacadas em (A) e (C). O quadro de linha contínua em (C) e (E) destaca as áreas fluorescentes. 


\subsection{Processamento histológico}

As orelhas foram fixadas em parafolmaldeído (PFA) $4 \%$ por 12 horas à $4{ }^{\circ} \mathrm{C}$, lavadas em PBS (3 vezes, 5 minutos cada), desidratadas em bateria crescente de etanol $(70 \%, 80 \%, 90 \%, 95 \%$ e 100\%, 30 minutos cada), diafanizadas em xilol (ou citrisolv) (3 banhos de 30 minutos cada) e por fim emblocadas em paraplast (3 banhos de 45 minutos cada). Foram realizados cortes com $5 \mu \mathrm{m}$ de espessura e estes colocados em lâminas previamente silanizadas (3-aminopropyltriethoxysilane - Sigma-Aldrich / A3648).

\subsection{Imunofluorescência indireta}

As lâminas foram desparafinadas com dois banhos em xilol (10 minutos cada) e reidratadas em bateria decrescente de etanol conforme protocolo de imunohistoquímica de fluorescência descrito abaixo. Todas as etapas foram realizadas a temperatura ambiente, excetuando se a incubação com o anticorpo primário.

1. Lavagem em bateria decrescente de etanol; $100 \%, 90 \%, 80 \%, 70 \% .3$ minutos cada;

2. Lavagem em PBS, 2 vezes, 5 minutos;

3. Lavagem em água destilada, 5 minutos;

4. Bloqueio da autofluorescência com Glicina 0,1 M em PBS por 10 minutos;

5. Lavagem em PBS por 5 minutos;

6. Lavagem em Triton 0,5\% em PBS, 2 vezes, 5 minutos cada;

7. Lavagem em PBS, 5 minutos;

8. Bloqueio de sítios inespecíficos com albumina bovina (BSA) $1 \%$ em PBS por 30 minutos; 
9. Incubação com anticorpo primário diluído em BSA $0,1 \%$ em PBS por 16 horas, a $4{ }^{\circ} \mathrm{C}$ em câmara úmida;

10. Lavagem em PBS, 4 vezes, 5 minutos;

11. Bloqueio com BSA $1 \%$ em PBS por 15 minutos;

12. Incubação com anticorpo secundário diluído em PBS, por 90 minutos, a temperatura ambiente, em câmara úmida e escura.

13. Incubação com Hoechst $33258(20 \mu \mathrm{g} / \mathrm{ml})$ diluído em tampão de citoesqueleto por 30 minutos.

14. Lavagem em PBS; 3 vezes, 10 minutos cada;

15. Montagem com lamínula e meio de montagem (glicerol/PBS - 1:1).

Os anticorpos utilizados para a caracterização das células estão descritos na Tabela 1

Tabela 1 - Relação dos anticorpos utilizados.

\begin{tabular}{c|l|c|c}
\cline { 2 - 4 } \multicolumn{1}{c|}{ Anticorpo } & Titulação & Catálogo \\
\hline \multirow{4}{*}{} & Mouse monoclonal IgG anti GFP & $1: 500$ & Sigma \#G6539 \\
\cline { 2 - 4 } & Mouse monoclonal IgG2a anti SM $\alpha$ A & $1: 500$ & Sigma \#A2547 \\
\cline { 2 - 4 } & $\begin{array}{l}\text { Mouse monoclonal IgG anti Platelet and Endothelial } \\
\text { Cell Adhesion Molecule (PECAM) }\end{array}$ & $1: 25$ & DSHB \#P2B1 \\
\cline { 2 - 4 } & Mouse monoclonal anti endothelial Nitric Oxide Syntase & $1: 50$ & BD \#610296 \\
\cline { 2 - 4 } & Goat polyclonal anti Cardiac Troponin I & $1: 200$ & HyTest \#4T21/2 \\
\cline { 2 - 4 } & Rabbit polyclonal anti GFP & $1: 1000$ & AbCam \#ab6556 \\
\hline \multirow{3}{*}{} & Donkey anti goat IgG Alexa 488 conjugate & $1: 700$ & Invitrogen \#A11055 \\
\cline { 2 - 4 } & Donkey anti mouse IgG Alexa 488 conjugate & $1: 700$ & Invitrogen \#A21202 \\
\cline { 2 - 4 } & Donkey anti rabbit IgG Alexa 488 conjugate & $1: 700$ & Invitrogen \#A21206 \\
\cline { 2 - 4 } & Goat anti mouse IgG2a Alexa 594 conjugate & $1: 700$ & Invitrogen \#A21135 \\
\cline { 2 - 4 } & Sheep anti mouse IgG Cy3 conjugate & $1: 700$ & Sigma \#C2181 \\
\cline { 2 - 4 } & Sheep anti rabbit IgG Cy3 conjugate & $1: 700$ & Sigma \#C2306 \\
\hline
\end{tabular}

\subsubsection{Aquisição e análise de imagem}


As imagens foram adquiridas utilizando microscópio de fluorescência Nikon (Eclipse E600) e microscópio confocal Zeiss (LSM 510 Meta). Para a análise das imagens utilizamos os programas Image Pro Plus e LSM Browse, respectivamente. 
4 RESULTADOS 


\subsection{Estabelecimento de um modelo de para estudo do potencial de diferenciação de células do PE}

Conforme descrito anteriormente, o PE é uma estrutura embrionária transitória da qual derivam as células que dão origem à circulação coronária. Como o objetivo principal deste trabalho é estudar o potencial de diferenciação destas células em um sítio adulto, num primeiro momento foi necessário estabelecer um modelo que permitisse sua diferenciação in vivo. Para tanto, o modelo desenvolvido por nós teve que seguir alguns requisitos; levando-se em conta o sítio embrionário normal no qual estes vasos são formados, nosso sistema modelo deveria ter: (1) a presença de tecido cardíaco; (2) um ambiente com vascularização reduzida e por fim (3) um local com uma baixa concentração de oxigênio.

Para testarmos o potencial de formação vascular dos precursores coronários, criar um modelo de neovascularização e analisar o comportamento das células do PE em sítio adulto buscamos na literatura por modelos que atendessem aos nossos requisitos e nos deparamos com o modelo utilizado por Fey et al.(1998), no estudo de drogas imunossupressoras, e primeiro descrito por Fulmer et al. (1963) no qual os mesmos usavam o transplante para o pavilhão auricular de um coração neonatal ou parte dele para analisar morfologia e função do órgão ectópico. $O$ transplante de um coração neonatal para o pavilhão auricular nos forneceu a base para 0 estabelecimento do modelo para a diferenciação das células do PE, uma vez que o pavilhão auricular é um tecido pouco vascularizado e provê uma baixa concentração de oxigênio para o tecido transplantado, atendendo assim a todos os requisitos supracitados. A adição do coração neonatal no sítio da orelha provavelmente produz um ambiente isquêmico ao órgão transplantado, o que seguramente funciona como um importante estímulo para a angiogênese e provavelmente vasculogênese, uma vez que hipóxia em geral e isquemia em especial levam a liberação local de vários fatores angiogenéticos (Semenza, 2007). 
Para transplantar o coração neonato para o pavilhão auricular de camundongos com o menor dano tecidual possível foram testadas diferentes ferramentas de inserção, desde trocateres (instrumento cirúrgico utilizado para punção de medula óssea) até agulhas hipodérmicas de diferentes calibres. A melhor ferramenta, ou seja, aquela que permitiu o transplante do coração com o mínimo de danos para o tecido foi a agulha hipodérmica 14G (Intra-cath), tendo esta o seu bizel retirado com o auxilio de uma lixa.

Como descrito anteriormente na seção de material e métodos, antes da transferência do tecido cardíaco para o pavilhão auricular um túnel foi confeccionado através da inserção da agulha hipodérmica entre a pele e cartilagem da orelha. Feito isso, o coração foi posicionado na abertura do túnel e inserido com o auxilio do Intracath. Duas semanas após a transferência do tecido cardíaco utilizando a metodologia supracitada, o coração encontrava-se sadio e mantendo a propriedade de inotropismo (relativa à capacidade do órgão de se contrair ativamente sem estímulo externo). As duas semanas após o transplante do coração foram importantes porque neste intervalo a maior parte da resposta inflamatória que se seguia ao procedimento já havia retornado a seus níveis basais, interferindo muito pouco em nossos resultados.

Estes corações transplantados são capazes de se integrar à rede vascular local, o que lhes permite continuar esta atividade contrátil e mostrar sobrevida, compatível com a realização dos experimentos que programamos. A integração a rede vascular locar, descrita acima por ser facilmente observada em material e métodos (Figura 10A).

Após o estabelecimento da melhor maneira de transferência do coração para o pavilhão auricular e tempo entre essa transferência e adição das células do PE, definimos nossos grupos experimentais.

Brevemente, nosso grupo experimental foi constituído de camundongos FVBWT que receberam, em um sítio no tecido subcutâneo auricular, transplante de um coração neonatal de animais FVB-WT. Quatorze dias após o transplante do coração, 
a pele do pavilhão auricular foi seccionada, o tecido epicárdico deste coração foi removido localmente por fricção e o miocárdio exposto foi recoberto com dois explantes de PE de embriões FVB-GFP no estágio de 9.5dpc (Grupo A). Foram testados diferentes períodos de tempo entre o transplante do coração e adição do PE (quatro e sete dias), não tendo observado diferenças significativas em relação à diferenciação dos precursores coronários. Os resultados apresentados a seguir, seguem o padrão apresentado na seção anterior (material e métodos).

O grupo B por sua vez, recebeu apenas o transplante de dois PEs de camundongos FVB-GFP no mesmo estágio. Para este grupo, diferentes metodologias para a transferência dos PEs foram testadas. A principio realizamos o transplante utilizando um capilar de vidro adaptado a uma mangueira de microinjeção, sem sucesso. Partimos então para a transferência dos PEs utilizando pinças de dissecção, na qual as estruturam foram posicionadas na ponta da pinça e inseridas através do túnel previamente realizado.

Como controle experimental, utilizamos nos ensaios de imunofluorescência (IF) cortes histológicos do pavilhão auricular com coração transplantado e também sem nenhuma estrutura transplantada.

Para o grupo que recebeu o enxerto de tecido cardíaco (grupo A), passadas as duas semanas observamos um aumento da rede vascular, tanto em número quanto em diâmetro dos vasos quando comparado com a rede de uma orelha controle (não transplantada), enquanto que no grupo $B$ esse aumento foi mais discreto (Figura 10A e C).

Nos primeiros transplantes do grupo A observamos grandes áreas fluorescentes sobre o tecido cardíaco, contudo após os ensaios de IF não era possível detectar nenhum sinal GFP+ nos cortes. A fluorescência inespecífica provavelmente era resultado de exsudato inflamatório pós procedimento. Devido a isso criamos um sistema visual de validação no qual nossas amostras quando colocadas em estereomicroscópio sob filtro para GFP apresentavam discretas 
regiões de fluorescência GFP+, estas mais compatíveis com uma possível diferenciação dos PEs transplantados.

Os experimentos foram validados através da metodologia descrita acima e seguimos então com os ensaios de IF para verificar a possível diferenciação das células provenientes do PE. Estes resultados serão apresentados a seguir.

\subsection{Células do PE se diferenciam em sítio adulto}

Para avaliar a incorporação de células GFP+ oriundas do PE nos transplantes realizados e investigar suas possíveis diferenciações, realizamos ensaios de imunofluorescência dupla para GFP combinado com diferentes marcadores: para tecido cardíaco a Troponina Cardíaca-1 (cTn-1), para células musculares lisas a Alfa Actina de Músculo Liso (SMaA), já como marcadores endoteliais PECAM (CD31) e Óxido Nítrico Sintase Endotelial (eNOS / NOS III), sendo o primeiro um marcador de ilhotas sanguíneas, precursores endoteliais e células terminalmente diferenciadas, e o último.marcador apenas para células diferenciadas.

Células GFP+ foram observadas na porção mais interna dos vasos sanguíneos, tanto no grupo que recebeu o transplante do coração seguido da transferência dos PEs (Figura 11A), quando no grupo que recebeu apenas os PEs (Figura 11B). Para verificar se as células derivadas do PE estariam se diferenciando em músculo liso, realizamos a dupla marcação para GFP e SMaA, a fim de verificar a existência de células marcadas por ambos os anticorpos. Num primeiro momento realizamos esta imunomarcação dupla em material dos animais do grupo $A$, que receberam um transplante de coração e posteriormente a transferência de dois PEs. Esta análise revelou que as células GFP+ não expressam SMaA e que estão sempre entre a camada muscular dos vasos e o seu lúmen, sugerindo então a diferenciação das células do PE em células endoteliais (Figura 11C). 
Uma vez que a IF dupla para GFP e o marcador de célula muscular lisa não foi positivo para SMaA para o grupo A, e as células positivas para GFP eram morfologicamente compatíveis com células endoteliais, resolvemos investigar a diferenciação dos PEs em células endoteliais.
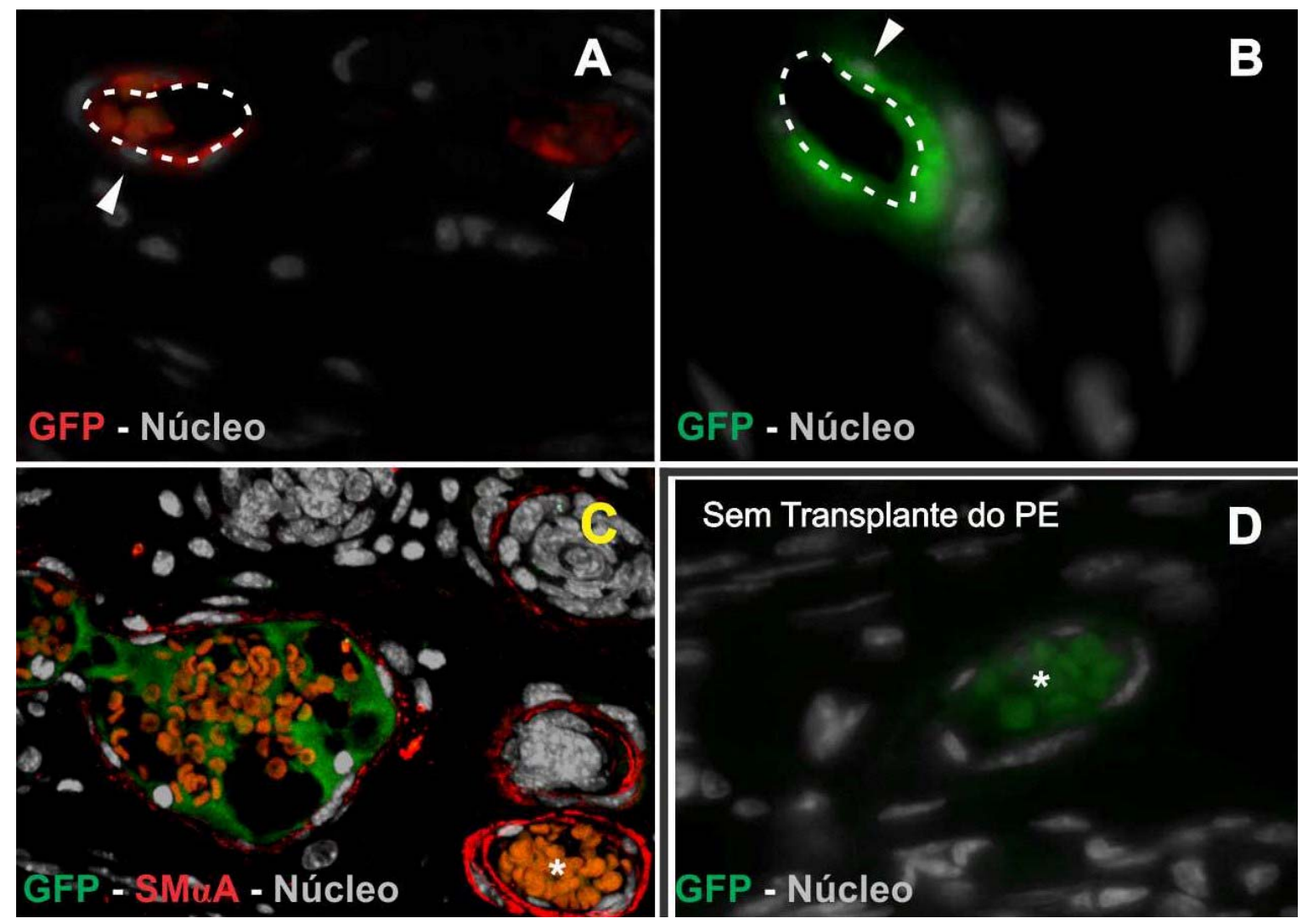

Figura 11. Células GFP+ foram encontradas entre a camada de células musculares lisas e o lúmen vascular. $(A, B, C, D)$ Imunomarcação para proteína verde fluorescente. (A, B) Células GFP+ foram encontradas na porção mais interna dos vasos (cabeça de seta) tanto no grupo $A$, que recebeu o transplante do coração e após duas semanas o transplante dos PEs (A) quanto nas lâminas pertencentes aos animais do grupo $B$, o qual recebeu apenas 0 transplante dos PEs (B). (C) Imunomarcação dupla para SM $\alpha$ A-GFP nas lâminas dos animais do grupo $A$ revelou a presença de células GFP+ entre o lúmen vascular e a camada de células musculares lisas. Não observamos sinal de marcação para GFP no controle negativo (D). O ruído derivado da auto-fluorescência das hemácias aparece destacado com asterisco (D).

\subsection{Diferenciação endotelial do PE em sítio adulto}


A natureza endotelial da contribuição do PE foi confirmada nos dois grupos através de dupla marcação com anticorpos anti-GFP juntamente com anticorpos contra eNOS ou proteína de adesão PECAM.

$\mathrm{Na}$ análise das IF dupla para PECAM (marcador de diferenciação precoce de células endoteliais e hemangioblastos) e GFP foi possível observar a presença de células imunomarcadas no endotélio vascular e também células sanguíneas positivas para ambos marcadores tanto no grupo que recebeu o enxerto cardíaco seguido dos PEs (Figura 12A-C), quanto do grupo que recebeu apenas a transferência dos explantes proepicárdicos (Figura 12H). Interessantemente, no grupo que recebeu o transplante apenas dos PEs, notamos a presença maior destes agregados celulares positivos para GFP (Figura 12G) - e, portanto derivados dos PEs transplantados - muito semelhante às ilhotas sanguíneas, descritas em seções anteriores. Sugerindo assim, que um dos meios de diferenciação dos PEs em células endoteliais foi via formação de ilhotas sanguíneas, fato confirmado pela presença de células nucleadas no interior desses agregados celulares (Figura 13B). Estas células nucleadas provavelmente correspondem aos precursores hematopoiéticos - hemangioblastos - encontrados no interior destas estruturas.

Já a dupla marcação para GFP e eNOS (marcador de diferenciação terminal de endotélio vascular) mostrou a presença de células diferenciadas a partir dos PEs $(\mathrm{GFP}+)$ somente no grupo que previamente recebeu o transplante do coração (Figura 12D-F). Este resultado fortemente sugere a necessidade da presença do tecido cardíaco para que as células provenientes do $P E$ se diferenciem terminalmente em células endoteliais. Provavelmente os fatores de crescimento e moléculas de sinalização proveniente do tecido cardíaco (Tomanek et al., 1999; Tomanek et al., 2001; Watanabe et al., 2006; Lavine et al., 2008) influenciam de alguma forma a diferenciação de células derivadas do PE para que estas, no mesmo intervalo de tempo, expressem o marcador de diferenciação terminal de endotélio. 


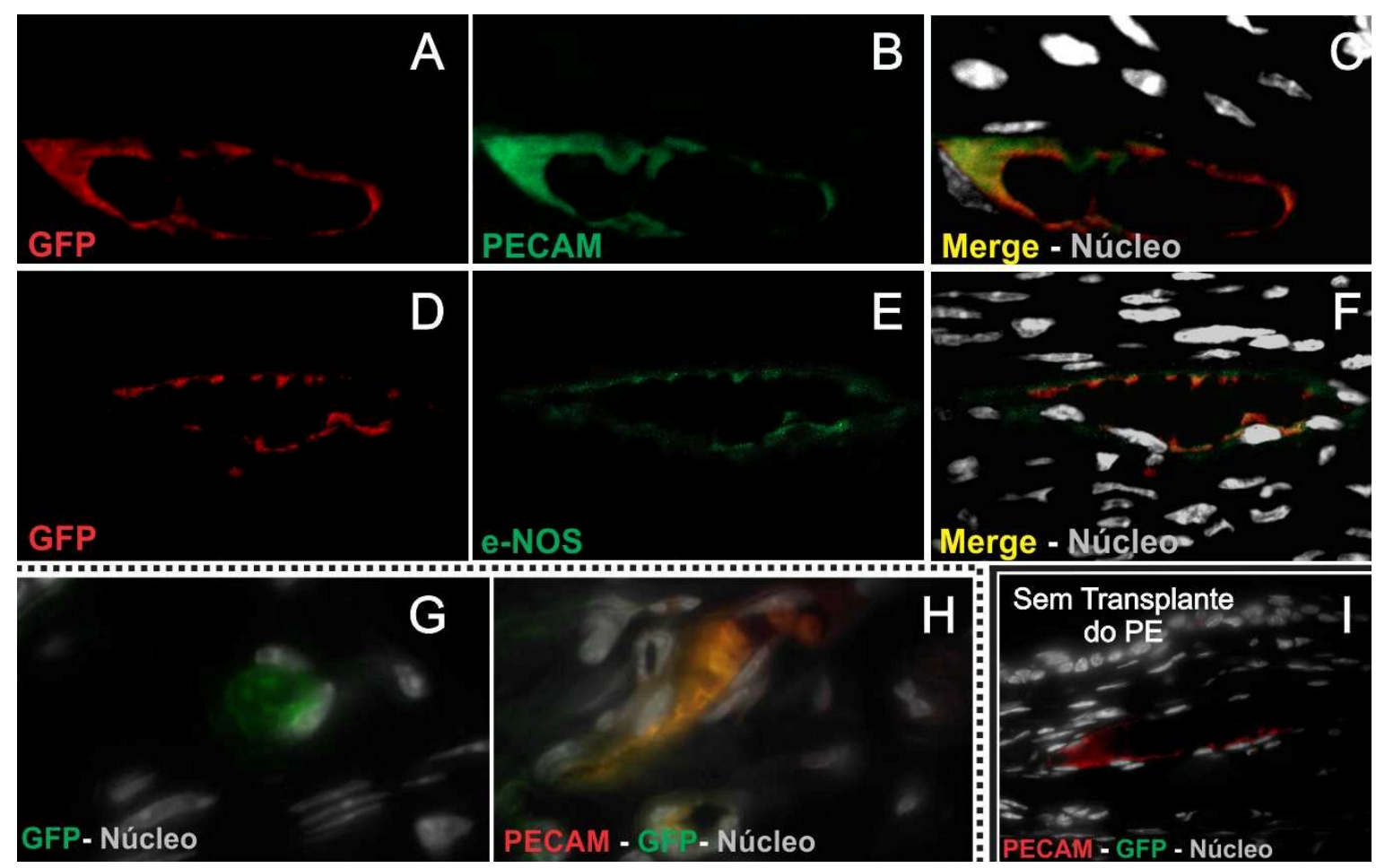

Figura 12. Dupla marcação para GFP e marcadores endoteliais revelou a presença de células derivadas do PE também como precursores endoteliais. Na análise das IF para PECAM e GFP notamos a presença de células duplamente marcadas no endotélio vascular para ambos marcadores tanto no grupo $A(A-C)$, quanto no grupo $B(H)$.Já na dupla marcação para GFP e eNOS, observamos a presença de células diferenciadas e positivas para ambos marcadores somente no grupo A (D-F). Nas IF do grupo que recebeu o transplante apenas dos PEs, notamos a presença de agregados celulares GFP+ $(G)$ muito semelhante às ilhotas sanguíneas. Não observamos sinal de marcação para GFP no controle negativo, tendo sido observada apenas a marcação para a proteína de adesão, PECAM (I).

\subsection{Células do PE não se diferenciam em cardiomiócitos}

Confirmada a natureza endotelial da diferenciação das células do PE transplantada para sítio adulto e a não diferenciação destas em células musculares lisas, precisávamos então, investigar se as células do PE estariam se diferenciando em cardiomiócitos, uma vez que Zhou et al. (2008) identificaram células derivadas do epicárdio se diferenciando em cardiomiócitos durante a cardiogênese (Zhou et al., 2008). 
A dupla IF contra GFP e cTn-1 mostrou, no grupo que recebeu o transplante do coração e dos PEs, extensa incorporação de células do nosso doador GFP+ em vasos sempre na periferia do enxerto (Figura 13A). Na análise das lâminas não foi observada presença de células derivadas do PE na substância do miocárdio (Figura 13) tampouco em dupla marcação positiva para c-Tn1. Mostrando que no modelo utilizado por nós, as células derivadas do PE não se diferenciam em cardiomiócitos e também invadem o tecido cardíaco, comportamento natural dessas células in situ, durante o desenvolvimento embrionário.

Semelhante ao encontrado nos ensaios de IF com marcadores endoteliais observamos também na IF dupla para GFP e c-Tn1 a presença dos agregados celulares GFP+ (Figuras 13B) discutido na seção anterior. É importante ressaltar que nem todas as células endoteliais dos vasos encontrados são positivas para GFP. $\mathrm{Na}$ Figura $13 \mathrm{C}$ podemos ver dois vasos na periferia do tecido cardíaco, um dos quais tem o endotélio GFP+ (cabeça de seta) enquanto no outro só observamos o ruído da auto-fluorescência das hemácias (asterisco). Indicando que as células diferenciadas a partir dos PEs transplantados não se integraram a toda malha vascular do local de transplante, mas sim contribuem para a formação/remodelamento dos vasos préexistentes. 

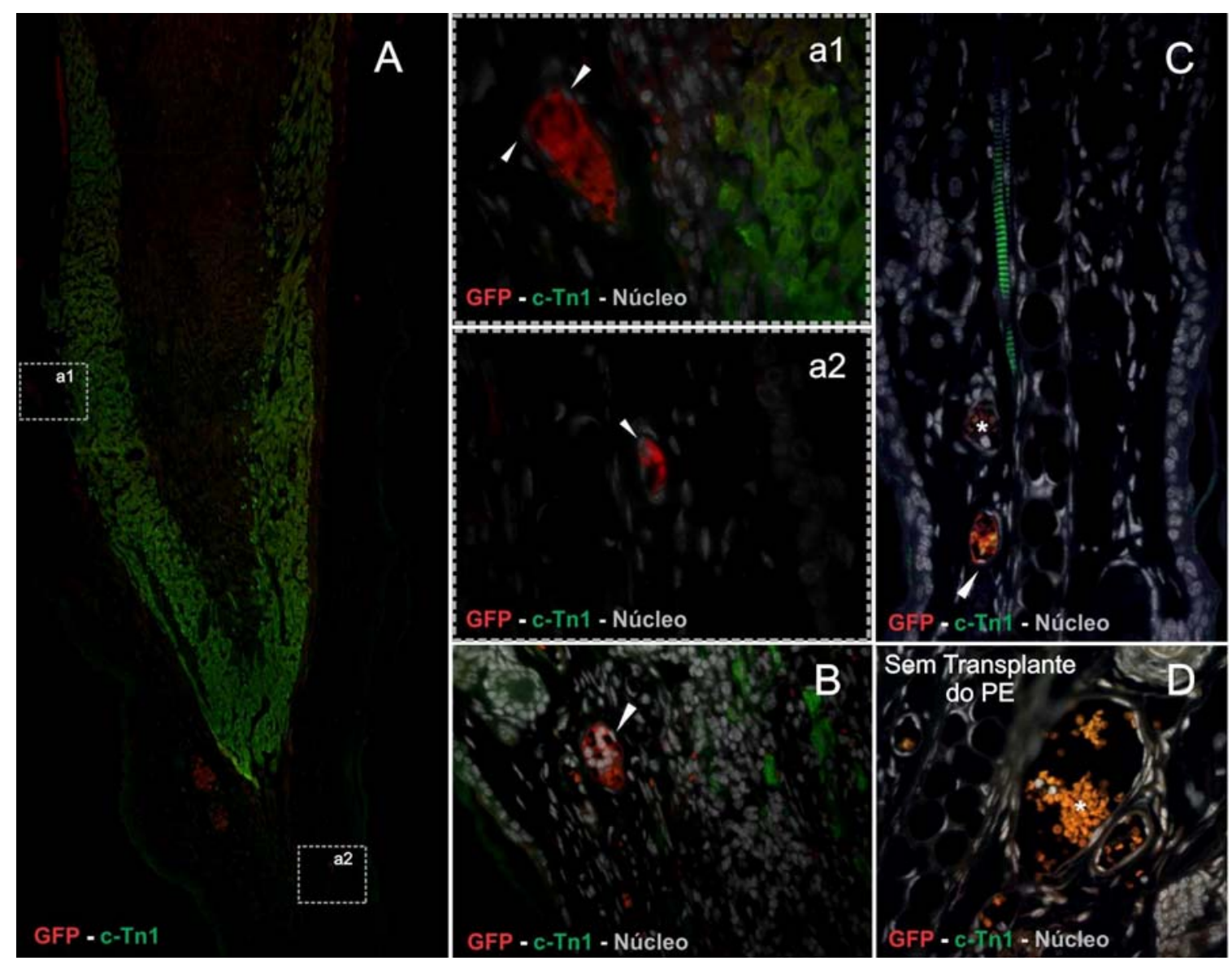

Figura 13. Células GFP+ não expressam troponina cardíaca (cTn-1). (A-C) Células GFP+ foram observadas em diferentes locais na periferia do enxerto cardíaco (a1-2), integrando vasos sanguíneos (a1-2, cabeça de seta em B e C) e constituindo estruturas semelhantes a ilhotas sanguíneas (a2, B); não foi observada dupla marcação com cTn-1. (D) Não foi observado sinal de marcação para GFP no controle negativo. O ruído derivado da autofluorescência das hemácias aparece destacado com asterisco (C, D).

\subsection{Sumário}

Nas seções descritas acima descrevemos os resultados relativos ao estabelecimento de um sistema modelo para a diferenciação dos precursores de vasos coronários em sítio adulto. Em resumo, na análise de nossas lâminas observamos células GFP+ diferenciadas a partir do PE na porção mais interna dos 
vasos sanguíneos; entre o lúmen vascular e a camada de músculo liso, sugerindo assim, a diferenciação do PE em células endoteliais. Esse dado foi confirmado com dupla imunomarcação para GFP-PECAM e GFP-eNOS nos dois grupos experimentais, tendo demonstrado que na presença do coração neonatal previamente transplantado para o pavilão auricular as células endotelias derivadas do PE diferenciam-se terminalmente (positivas para eNOS e GFP) enquanto que apenas com o transplante dos PEs encontramos uma maior presença de agregados celulares semelhante a ilhotas sanguíneas.

Durante o desenvolvimento embrionário e formação dos vasos coronários, o PE é responsável pela formação das células endoteliais, músculo liso e fibroblastos intersticiais, contudo em nossos resultados só observamos a diferenciação destas células em endotélio, não tendo observado dupla marcação para SMaA tampouco cTn1. 


\section{DISCUSSÃO}


O estabelecimento do sistema vascular sanguíneo ocorre relativamente cedo durante o desenvolvimento e é caracterizado pela diferenciação de precursores hematopoiéticos e endoteliais, agregados em estruturas denominadas ilhotas sanguíneas. A agregação in situ destes angioblastos forma um plexo capilar em um processo chamado vasculogênese. A expansão deste plexo capilar por sua vez se da através de um fenômeno conhecido como angiogênese. Já o remodelamento da rede vascular, em geral no organismo adulto, denomina-se arteriogênese (Risau e Flamme, 1995; Carmeliet, 2000b).

Durante a cardiogênese os vasos responsáveis pela nutrição do músculo cardíaco se estabelecem logo após a formação do epicárdio (formado a partir do proepicárdio (PE)) e diferenciação de algumas destas células que, sob estímulo de diferentes fatores adquirem características de células mesenquimais, migrando e povoando espaço subepicárdico e miocárdio e estabelecendo, desse modo, a circulação coronária (Reese et al., 2002) através dos processos descritos no parágrafo anterior.

Nas últimas décadas diversos grupos vêm trabalhando com o PE a fim de entender melhor as vias moleculares envolvidas na formação dos vasos coronários (Lavine et al., 2008), os padrões morfológicos presentes durante o estabelecimento da circulação coronária (Lie-Venema et al., 2007), sua origem no PE (Viragh et al., 1993; Perez-Pomares et al., 2002b), o potencial vasculogênico/angiogênico destes precursores (Guadix et al., 2006; Perez-Pomares et al., 2006; Cai et al., 2008; Zhou et al., 2008; Smart et al., 2009) e por fim, os fatores envolvidos na diferenciação do PE (Watanabe et al., 2006; Azambuja et al., 2010).

Compondo essa fonte de esforços para compreender melhor a biologia de diferenciação das células provenientes do PE, neste trabalho nós estabelecemos um modelo em sítio adulto para o estudo do processo de diferenciação dos precursores dos vasos coronários concentrados no PE. Para tanto utilizamos, ora o transplante de um coração neonatal associado ao transplante dos PEs para o pavilhão auricular de camundongos adultos, ora apenas a transferência dos PEs para o subcutâneo auricular. 


\subsection{Vasculogênese e angiogênese no adulto}

Como descrito na seção anterior, em nossos experimentos observamos um aumento da rede vascular, no grupo que recebeu o enxerto cardíaco seguido do transplante dos PEs (grupo A), tanto em número quanto em diâmetro dos vasos quando comparado com a rede vascular de uma orelha controle (não transplantada), enquanto que no grupo $B$ esse aumento foi mais discreto.

Até recentemente acreditava-se que no adulto os vasos eram formados apenas através da proliferação e diferenciação de células endoteliais em um processo de angiogênese, contudo hoje se sabe que processos vasculogênicos também ocorrem no adulto através da mobilização de células tronco da medula óssea (Carmeliet, 2000a; Smart et al., 2009; Kirton e Xu, 2010).

Nos organismos adultos, a neo-formação vascular ocorre tanto sob condições patológicas quanto fisiológicas. A angiogênese patológica em geral é induzida como resposta inflamatória e mediada por monócitos/macrófagos, plaquetas, mastócitos e outros leucócitos inflamatórios responsáveis por secretar fatores angiogênicos, como VEGF, e recrutar células para os sítios de inflamação (Carmeliet, 2000a). A angiogênese fisiológica por sua vez ocorre em resposta a uma maior necessidade de nutrientes e oxigênio, sendo mediada principalmente por fatores induzidos por hipóxia (HIF-1) e VEGF (Semenza, 2007; Smart et al., 2009).

Nós sabemos que parte do aumento vascular na região de transplante provavelmente foi uma resposta inflamatória ao procedimento cirúrgico, mas também acreditamos em uma resposta fisiológica.

Como dito nas seções iniciais deste trabalho, o miocárdio responde ao estresse através da ativação de mecanismos adaptativos que tendem a limitar os danos causados pelo evento; sendo que o objetivo final seria preservar a integridade e a função do órgão. O coração neonatal transplantado encontra no sítio da orelha um ambiente com uma concentração baixa de oxigênio, estímulo suficiente para desencadear vias pró angiogênicas e um aumento na rede vascular local, evidência facilmente observada em nossos resultados apresentados na seção anterior. 
Acreditamos que no grupo $A$, que recebeu o transplante do coração neonatal seguido dos explantes proepicárdicos, o processo angiogênico foi favorecido. $O$ tecido cardíaco enxertado, devido à hipóxia começou a produzir e secretar fatores de crescimento pró angiogênicos (como HIF-1 e VEGF) que estimularam o aumento da rede vascular local; evento amplificado pela adição dos PEs, cujas células se diferenciaram e foram sendo adicionadas a rede vascular em expansão. Já no grupo $B$, a menor concentração destes fatores devido a ausência do enxerto cardíaco explica a diferença em relação à malha vascular da orelha.

Sabemos que eventos isquêmicos, em especial hipóxia são reconhecidamente os principais estímulos para que ocorra neo-formação vascular. Mediado por HIF-1a, a hipóxia leva a um aumento na expressão dos mesmos fatores pró angiogênicos responsáveis pelo desenvolvimento dos vasos coronários, incluindo FGF-2, VEGF e seus receptores, FLK-1 e FLT-1 (Tomanek, 2005; Semenza, 2007; Smart et al., 2009).

Resumindo, no grupo A notamos um aumento no número e diâmetro dos vasos que depende da presença do coração neonatal, previamente transferido para o pavilhão auricular, secretando fatores de crescimento e diferenciação vascular enquanto que no grupo B a ausência do tecido cardíaco e, portanto, destes fatores pró angiogênicos justificam a malha vascular reduzida quando comparada ao grupo anterior.

\subsection{Um modelo para diferenciação do PE em sítio adulto}

Os vasos coronários se desenvolvem a partir de ilhotas sanguíneas que são constituídas por agregados de células precursoras endoteliais e hematopoiéticas (Rongish et al., 1996; Ratajska et al., 2008). Estas ilhotas sanguíneas então se fundem para formar os plexos capilares ou canais vasculares primitivos.

$\mathrm{Na}$ análise de nossos resultados da IF dupla para PECAM-GFP notamos a presença de células imunomarcadas no endotélio vascular e também células sanguíneas positivas para ambos marcadores tanto no grupo que recebeu o enxerto cardíaco seguido dos PEs (grupo A), quanto do grupo que recebeu apenas a 
transferência dos PEs (grupo B). Neste último grupo, notamos a presença maior destas ilhotas sanguíneas positivas para GFP e, portanto derivados dos PEs transplantados. Demonstrando desta forma que um dos meios de diferenciação dos PEs em células endoteliais foi via formação de ilhotas sanguíneas.

Tomanek et al. (1999) utilizando retrovirus para a marcação de células do PE mostraram que os eritrócitos no espaço subepicárdico derivam dos progenitores proepicárdicos que se diferenciaram em eritroblastos e precursores endoteliais (Tomanek et al., 1999). Isso parece consistente com nossos dados que mostraram a presença de agregados celulares semelhante a ilhotas sanguíneas em ambos grupos experimentais.

Sabemos que dependendo da disponibilidade local de alguns fatores de crescimento como PDGF, VEGF ou bFGF, as células diferenciadas a partir do PE podem se diferenciar em células de músculo liso ou células endoteliais, respectivamente (Perez-Pomares et al., 2002a; Ratajska et al., 2008). Contudo, não observamos a diferenciação dos PEs transplantados em células musculares lisas. Provavelmente isto se deve a: (1) ausência de quantidade suficiente destes fatores de crescimento necessários à diferenciação dos PEs em músculo liso e também, (2) ao tempo entre o transplante dos PEs e coleta do material ter sido insuficientes para que houvesse a diferenciação destas em células musculares lisas.

Em um trabalho muito elegante, Watanabe et al. (2006) testaram diferentes fatores de crescimento em culturas in vitro do explante do PE, chegando a conclusão de que para a diferenciação do PE em canais vasculares é essencial a presença de soro fetal bovino, e que o início do processo vasculogênico é controlado diretamente por bFGF, que atua nas células endoteliais, e indiretamente por VEGF, que sinaliza para o crescimento vascular. VEGF e seus receptores (FLK-1 E FLT-1) possuem importante papel tanto na vasculogênese quanto nos processos de angiogênese, isso porque atuam regulando as interações entre as células endoteliais e células e matriz extracelular (Watanabe et al., 2006).

No modelo e metodologia utilizada é difícil determinar os fatores de crescimento que estiveram atuantes em nossos grupos experimentais durante os dias que se seguiram ao transplante do coração neonatal e PEs no grupo $A$ e dos explantes proepicárdicos no grupo $B$, portanto difícil estabelecer o papel de um ou 
outro fator na diferenciação do PE em endotélio e a não diferenciação em músculo liso e cardiomiócito.

\subsection{Potencial vasculogênico e angiogênico do PE em sítio adulto}

O PE é uma estrutura transitória e as células derivadas deste adquirem características migratórias e invasivas quando sofrem a transformação epitélio mesenquimal (TEM) (Manner et al., 2001; Tomanek, 2005; Winter e Gittenberger-de Groot, 2007). Após a formação do epicárdio e TEM as células derivadas do epicárdio migram para o espaço subepicárdio e para a substância do miocárdio onde se diferenciam em endotélio, músculo liso e fibroblastos, formando os vasos coronários (Reese et al., 2002; Tomanek, 2005).

A análise dos nossos dados da dupla marcação para GFP e c-Tn1 revelou que as células que se diferenciaram a partir do $\mathrm{PE}$, portanto $\mathrm{GFP}+$, não penetraram no miocárdio - evento que normalmente ocorre durante a formação dos vasos coronários (Reese et al., 2002; Tomanek, 2005; Watanabe et al., 2006) - e sim povoaram a região em torno do enxerto cardíaco, tampouco se diferenciam em cardiomiócitos (Zhou et al., 2008), provavelmente pela ausência ou baixa concentração de algum fator importante neste evento ou mesmo pelo coração transplantado já ser um órgão adulto, não permitindo este fenômeno ocorra..

Guadix et al. (2006) utilizando quimeras galinha/codorna demonstraram, que o explante do PE transplantado para diferentes locais, tais como broto dos membros, e broto hepático no embrião de galinha, uma grande incidência de vasos derivados do PE de codorna pode ser observada, comprovando assim seu alto poder de formação vascular em sítio embrionário (Guadix et al., 2006).

Contudo, recentemente Red-Horse et al. (2010) demonstraram que as artérias coronárias em camundongos não derivam do $P E$ e sim da dediferenciação e reprogramação de células endoteliais do seio venoso e migração destas da região de influxo pela parede miocárdica com ainda uma pequena contribuição de células endocárdicas neste processo (Red-Horse et al., 2010). A controvérsia gerada em 
três décadas de trabalhos que, utilizando diferentes técnicas e modelos (Viragh e Challice, 1981; Perez-Pomares et al., 1997; Watanabe et al., 2006), demonstraram a origem dos vasos coronários a partir do PE não invalida os dados apresentados no presente trabalho, uma vez que aqui estabelecemos um modelo para a diferenciação destas células em um ambiente diferente do contexto embrionário. Acreditamos que talvez a dediferenciação e reprogramação das células do seio venoso seja ou uma fonte alternativa de células para a formação das coronárias, além do que mais trabalhos serão necessários no futuro a fim de comprovar a origem exata de artérias e veias do sistema coronário durante a embriogênese cardíaca.

Em nossa presente investigação o transplante dos explantes dos PEs nos diferentes grupos nos permite afirmar que quando transplantados para sítio adulto o PE parece participar tanto do processo de vasculogênese (presença de ilhotas sanguíneas) quanto do processo de angiogênese (integração das células GFP+ nos vasos pré existentes) (Figura 14). No processo de vasculogênese a fusão dos angioblastos (precursores endoteliais) e formação do endotélio é o primeiro passo para o estabelecimento de um vaso sanguíneo (Flamme et al., 1997).

Baseados em nossos dados constatamos que o PE pode se diferenciar em células precursoras endoteliais e formar um novo vaso sanguíneo (GFP+) (Figura 12F). Já no processo de angiogênese o que observamos foi a presença de células endoteliais GFP+ intercaladas entre as células do animal hospedeiro (células não GFP) (Figura 13C), provavelmente numa tentativa de reconstituir o endotélio porventura lesado ou numa tentativa de ampliar a malha circulatória local, mostrando que as células derivadas do PE contribuem nos dois processos de formação vascular.

Devemos lembrar que durante o desenvolvimento as células derivadas PE, após a formação do epicárdio, são responsáveis pelo estabelecimento do sistema vascular coronário, formando endotélio, músculo liso e fibroblastos. A adição do PE, sabidamente uma estrutura com características multipotenciais e comprovado potencial vasculogênico e angiogênico, em um contexto diferente do qual ele estaria condicionado a formação vascular e tendo como resultado a participação deste nos processos descritos nos parágrafos anteriores com a diferenciação em células endoteliais nos permite afirmar que de fato estas células possuem também um 
potencial vasculogênico/angiogênico em sítio adulto, podendo ser exploradas como modelo para revascularização cardíaca e recuperação de tecidos vasculares (Smart et al., 2009; Kirton e Xu, 2010).
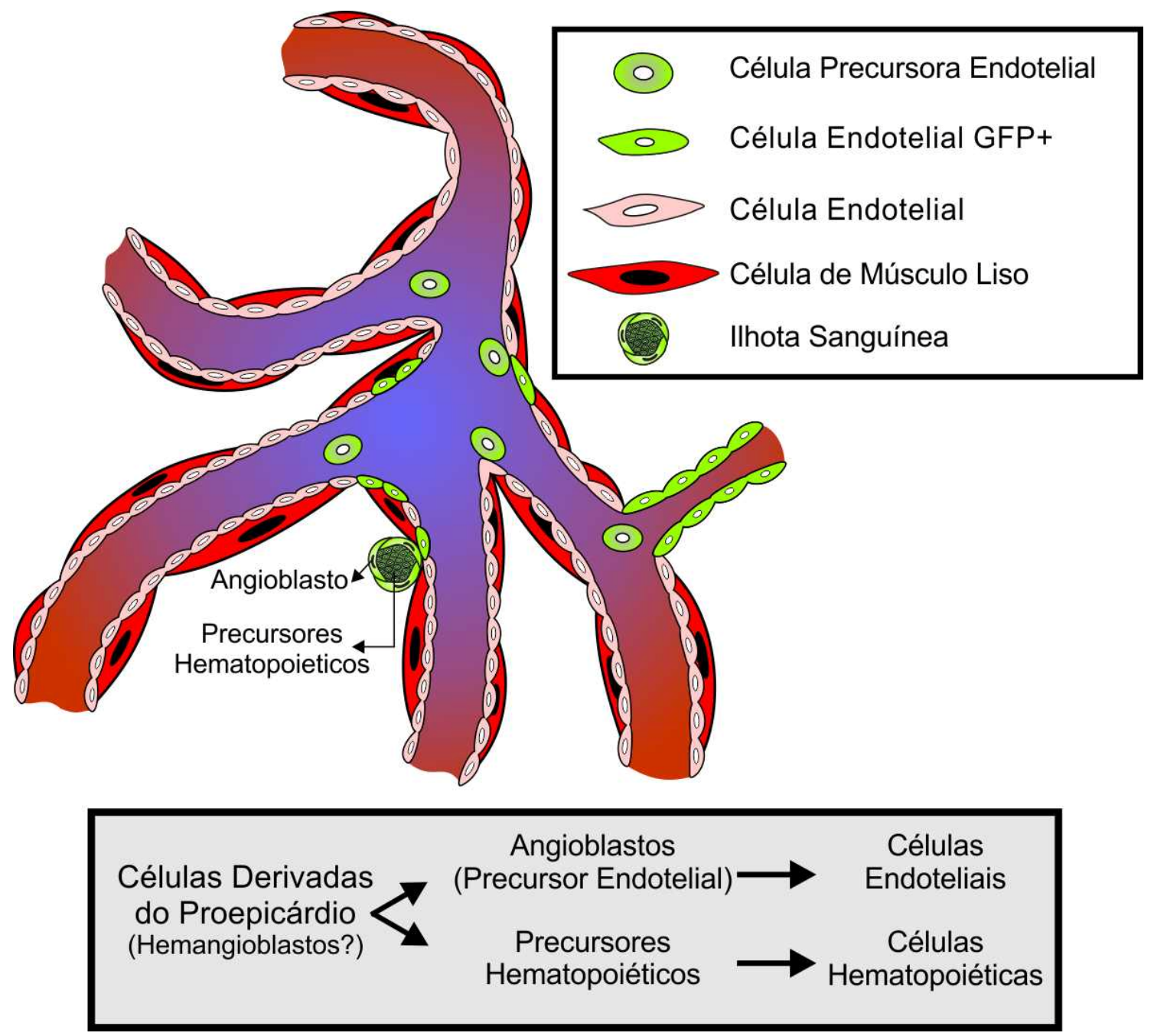

Figura 14. Diferenciação do PE em sítio adulto. Quando transplantado para sítio adulto o PE parece participar tanto de um processo de vasculogênese, via formação de ilhotas sanguíneas (GFP+), diferenciação destas em células precursoras endoteliais e hematopiéticas (GFP+) e formação de um novo vaso GFP+ (vaso com endotélio verde a direita), quanto de um processo de angiogênese no qual células GFP+ (células verdes intercalada entre células não GFP), derivadas do PE se diferenciaram e foram adicionadas a um vaso do animal hospedeiro (FVB-WT).

\subsection{Precursores endoteliais no reparo vascular}


O primeiro passo na formação dos vasos sanguíneos é a diferenciação dos precursores endoteliais em células endoteliais vasculares, que mais tarde irão constituir a superfície interna de revestimento dos vasos maduros [revisado por (Ratajska et al., 2006)]. Dentro do embrião, as células endoteliais se diferenciam a partir da mesoderme como angioblastos isolados, onde ocorre a formação das ilhotas sanguíneas em associação com os precursores hematopoiéticos. Os angioblastos então migram e fundem-se a outros angioblastos formando uma estrutura semelhante a um labirinto vascular (Risau e Flamme, 1995; Flamme et al., 1997; Ratajska et al., 2006). Em seguida, esta malha vascular primitiva é expandida e passa por um processo de remodelamento (Risau e Flamme, 1995).

Atualmente as doenças vasculares, em especial doenças nas artérias coronárias são a principal causa de morte no mundo e a integridade da camada endotelial é essencial para proteção contra o desenvolvimento destes processos patológicos (Kirton e Xu, 2010; Olivey e Svensson, 2010). Para muitos tipos de doença cardíaca, como em cardiopatias isquêmicas, vem-se utilizando o transplante de células tronco cujo objetivo principal é a recuperação da contratilidade do órgão através da ampliação da malha circulatória.

A descoberta das células progenitoras endoteliais circulantes e sua habilidade de contribuir com o processo de vasculogênese pós natal fez destas um alvo interessantíssimo no estudo de neovascularização em tecidos que sofreram eventos isquêmicos ou hipóxicos (Asahara et al., 1997).

Pensando nisso, novas descobertas que contribuam para o entendimento do processo de diferenciação vascular poderiam ser aplicadas para dirigir a diferenciação de células multipotentes e progenitoras ao fenótipo vascular desejado antes da sua inserção no sítio lesado.

Sabendo que são as células precursoras endoteliais que iniciam o processo de formação ou expansão vascular nossa proposta com este trabalho foi compreender melhor os mecanismos embrionários nos processos de vasculogênese e angiogênese e comprovar sua potencialidade em sítio adulto para, no futuro, contribuir com o aprimoramento das técnicas de terapia celular e com o desenvolvimento de novas estratégias para terapias de regeneração cardiovascular, contribuindo desta forma para elucidar as vias de sinalização que dirigem a 
diferenciação de células multipotentes para os fenótipos encontrados no leito vascular. 


\section{CONCLUSÕES}


- O modelo de transplante do PE para o pavilhão auricular é uma abordagem válida no estudo da diferenciação dos precursores dos vasos coronários em sítio adulto.

- O transplante do coração neonatal para o sítio auricular de um camundongo adulto provavelmente fornece os fatores de crescimento necessários para processos de vascularização e neovascularização iniciado pelo PE.

- Quando transplantado para sítio adulto o PE diferencia-se e participa dos processos de vasculogênese, iniciando a formação de novos vasos sanguíneos via formação de ilhotas sanguíneas e de um processo angiogênico, diferenciando-se em células endoteliais que se incorporaram ao endotélio dos vasos já existentes.

- Com as metodologias utilizadas é difícil determinar os fatores de crescimento que estiveram atuantes em nossos grupos experimentais durante os dias que se seguiram ao transplante do coração neonatal e PEs no grupo A e dos explantes proepicárdicos no grupo $B$, portanto difícil estabelecer o papel de um ou outro fator na diferenciação do PE em endotélio e a não diferenciação em músculo liso e cardiomiócito, portanto, novos experimentos utilizando a mesma abordagem e novas metodologias serão necessários a fim de estabelecer as vias moleculares atuantes nestes processos de formação e neo-formação vascular.

- Em resumo, a adição do PE em um contexto diferente do qual ele estaria condicionado à formação vascular e tendo como resultado a participação deste nos processos apresentados neste trabalho nos permite afirmar que estas células possuem também um potencial vasculogênico/angiogênico em sítio adulto, podendo ser exploradas como potencial modelo para revascularização cardíaca e recuperação de tecidos vasculares. 
REFERÊNCIAS 


\section{REFERÊNCIAS ${ }^{1}$}

Asahara T, Murohara T, Sullivan A, Silver M, van der Zee R, Li T et al. Isolation of putative progenitor endothelial cells for angiogenesis. Science. 1997;275(5302):9647.

Azambuja AP, Portillo-Sanchez V, Rodrigues MV, Omae SV, Schechtman D, Strauss $\mathrm{BE}$ et al. Retinoic acid and VEGF delay smooth muscle relative to endothelial differentiation to coordinate inner and outer coronary vessel wall morphogenesis. Circ Res. 2010;107(2):204-16.

Balsam LB, Wagers AJ, Christensen JL, Kofidis T, Weissman IL, Robbins RC. Haematopoietic stem cells adopt mature haematopoietic fates in ischaemic myocardium. Nature. 2004;428(6983):668-73.

Black BL. Transcriptional pathways in second heart field development. Semin Cell Dev Biol. 2007;18(1):67-76.

Brade T, Kumar S, Cunningham TJ, Chatzi C, Zhao X, Cavallero S et al. Retinoic acid stimulates myocardial expansion by induction of hepatic erythropoietin which activates epicardial Igf2. Development. 2011;138(1):139-48.

Brade $\mathrm{T}$, Manner J, Kuhl M. The role of Wnt signalling in cardiac development and tissue remodelling in the mature heart. Cardiovasc Res. 2006;72(2):198-209.

Brand T. Heart development: molecular insights into cardiac specification and early morphogenesis. Dev Biol. 2003;258(1):1-19.

Buckingham $M$, Meilhac $S$, Zaffran $S$. Building the mammalian heart from two sources of myocardial cells. Nat Rev Genet. 2005;6(11):826-35.

Cai CL, Martin JC, Sun Y, Cui L, Wang L, Ouyang K et al. A myocardial lineage derives from Tbx18 epicardial cells. Nature. 2008;454(7200):104-8.

Carmeliet P. Developmental biology. One cell, two fates. Nature. 2000a;408(6808):43-5.

Carmeliet P. Mechanisms of angiogenesis and arteriogenesis. Nat Med. 2000b;6(4):389-95.

${ }^{1}$ De acordo com: International Committee of Medical Journal Editors. Uniform requirements for manuscripts submitted to Biomedical Journal: sample references. Available from: http://www.icmje.org [2007 May 22]. 
Crispino JD, Lodish MB, Thurberg BL, Litovsky SH, Collins T, Molkentin JD et al. Proper coronary vascular development and heart morphogenesis depend on interaction of GATA-4 with FOG cofactors. Genes Dev. 2001;15(7):839-44.

Davis S, Aldrich TH, Jones PF, Acheson A, Compton DL, Jain V et al. Isolation of angiopoietin-1, a ligand for the TIE2 receptor, by secretion-trap expression cloning. Cell. 1996;87(7):1161-9.

Dimmeler S, Zeiher AM, Schneider MD. Unchain my heart: the scientific foundations of cardiac repair. J Clin Invest. 2005;115(3):572-83.

Fey TA, Krause RA, Hsieh GC, Andrews JM, Bretheim PT, Morgan SJ et al. Improved methods for transplanting split-heart neonatal cardiac grafts into the ear pinna of mice and rats. J Pharmacol Toxicol Methods. 1998;39(1):9-17.

Flamme I, Frolich T, Risau W. Molecular mechanisms of vasculogenesis and embryonic angiogenesis. J Cell Physiol. 1997;173(2):206-10.

Fulmer RI, Cramer AT, Liebelt RA, Liebelt AG. Transplantation of Cardiac Tissue into the Mouse Ear. Am J Anat. 1963;113:273-85.

Gittenberger-de Groot AC, Blom NM, Aoyama N, Sucov H, Wenink AC, Poelmann $\mathrm{RE}$. The role of neural crest and epicardium-derived cells in conduction system formation. Novartis Found Symp. 2003;250:125-34.

Guadix JA, Carmona R, Munoz-Chapuli R, Perez-Pomares JM. In vivo and in vitro analysis of the vasculogenic potential of avian proepicardial and epicardial cells. Dev Dyn. 2006;235(4):1014-26.

Harvey RP. Patterning the vertebrate heart. Nat Rev Genet. 2002;3(7):544-56.

Hatcher CJ, Diman NY, Kim MS, Pennisi D, Song Y, Goldstein MM et al. A role for Tbx5 in proepicardial cell migration during cardiogenesis. Physiol Genomics. 2004;18(2):129-40.

Hochgreb T, Linhares VL, Menezes DC, Sampaio AC, Yan CY, Cardoso WV et al. A caudorostral wave of RALDH2 conveys anteroposterior information to the cardiac field. Development. 2003;130(22):5363-74. 
Ishii Y, Langberg JD, Hurtado R, Lee S, Mikawa T. Induction of proepicardial marker gene expression by the liver bud. Development. 2007;134(20):3627-37.

Kalman F, Viragh S, Modis L. Cell surface glycoconjugates and the extracellular matrix of the developing mouse embryo epicardium. Anat Embryol (Berl). 1995;191(5):451-64.

Kaufman $\mathrm{MH}$, Navaratnam V. Early differentiation of the heart in mouse embryos. J Anat. 1981;133(Pt 2):235-46.

Kirton JP, Xu Q. Endothelial precursors in vascular repair. Microvasc Res. 2010;79(3):193-9.

Lavine KJ, Long F, Choi K, Smith C, Ornitz DM. Hedgehog signaling to distinct cell types differentially regulates coronary artery and vein development. Development. 2008;135(18):3161-71.

Lavine KJ, White AC, Park C, Smith CS, Choi K, Long F et al. Fibroblast growth factor signals regulate a wave of Hedgehog activation that is essential for coronary vascular development. Genes Dev. 2006;20(12):1651-66.

Li P, Pashmforoush M, Sucov HM. Retinoic acid regulates differentiation of the secondary heart field and TGFbeta-mediated outflow tract septation. Dev Cell. 2009;18(3):480-5.

Lie-Venema H, van den Akker NM, Bax NA, Winter EM, Maas S, Kekarainen T et al. Origin, fate, and function of epicardium-derived cells (EPDCs) in normal and abnormal cardiac development. ScientificWorldJournal. 2007;7:1777-98.

Lin SC, Dolle P, Ryckebusch L, Noseda M, Zaffran S, Schneider MD et al. Endogenous retinoic acid regulates cardiac progenitor differentiation. Proc Natl Acad Sci U S A. 2010;107(20):9234-9.

Manner J. Experimental study on the formation of the epicardium in chick embryos. Anat Embryol (Berl). 1993;187(3):281-9.

Manner J. Does the subepicardial mesenchyme contribute myocardioblasts to the myocardium of the chick embryo heart? A quail-chick chimera study tracing the fate of the epicardial primordium. Anat Rec. 1999;255(2):212-26. 
Manner J. On rotation, torsion, lateralization, and handedness of the embryonic heart loop: new insights from a simulation model for the heart loop of chick embryos. Anat Rec A Discov Mol Cell Evol Biol. 2004;278(1):481-92.

Manner J, Perez-Pomares JM, Macias D, Munoz-Chapuli R. The origin, formation and developmental significance of the epicardium: a review. Cells Tissues Organs. 2001;169(2):89-103.

Moorman A, Webb S, Brown NA, Lamers W, Anderson RH. Development of the heart: (1) formation of the cardiac chambers and arterial trunks. Heart. 2003;89(7):806-14.

Murry CE, Soonpaa MH, Reinecke H, Nakajima H, Nakajima HO, Rubart M et al. Haematopoietic stem cells do not transdifferentiate into cardiac myocytes in myocardial infarcts. Nature. 2004;428(6983):664-8.

Olivey HE, Svensson EC. Epicardial-myocardial signaling directing coronary vasculogenesis. Circ Res. 2010;106(5):818-32.

Orlic D, Kajstura J, Chimenti S, Jakoniuk I, Anderson SM, Li B et al. Bone marrow cells regenerate infarcted myocardium. Nature. 2001;410(6829):701-5.

Perez-Pomares JM, Carmona R, Gonzalez-Iriarte M, Atencia G, Wessels A, MunozChapuli R. Origin of coronary endothelial cells from epicardial mesothelium in avian embryos. Int J Dev Biol. 2002a;46(8):1005-13.

Perez-Pomares JM, Macias D, Garcia-Garrido L, Munoz-Chapuli R. Contribution of the primitive epicardium to the subepicardial mesenchyme in hamster and chick embryos. Dev Dyn. 1997;210(2):96-105.

Perez-Pomares JM, Macias D, Garcia-Garrido L, Munoz-Chapuli R. The origin of the subepicardial mesenchyme in the avian embryo: an immunohistochemical and quailchick chimera study. Dev Biol. 1998;200(1):57-68.

Perez-Pomares JM, Mironov V, Guadix JA, Macias D, Markwald RR, Munoz-Chapuli $R$. In vitro self-assembly of proepicardial cell aggregates: an embryonic vasculogenic model for vascular tissue engineering. Anat Rec A Discov Mol Cell Evol Biol. 2006;288(7):700-13.

Perez-Pomares JM, Phelps A, Sedmerova M, Carmona R, Gonzalez-Iriarte M, Munoz-Chapuli $R$ et al. Experimental studies on the spatiotemporal expression of 
WT1 and RALDH2 in the embryonic avian heart: a model for the regulation of myocardial and valvuloseptal development by epicardially derived cells (EPDCs). Dev Biol. 2002b;247(2):307-26.

Ratajska A, Czarnowska E, Ciszek B. Embryonic development of the proepicardium and coronary vessels. Int J Dev Biol. 2008;52(2-3):229-36.

Ratajska A, Czarnowska E, Kolodzinska A, Kluzek W, Lesniak W. Vasculogenesis of the embryonic heart: origin of blood island-like structures. Anat Rec A Discov Mol Cell Evol Biol. 2006;288(3):223-32.

Red-Horse K, Ueno H, Weissman IL, Krasnow MA. Coronary arteries form by developmental reprogramming of venous cells. Nature. 2010;464(7288):549-53.

Reese DE, Mikawa T, Bader DM. Development of the coronary vessel system. Circ Res. 2002;91(9):761-8.

Risau W. Mechanisms of angiogenesis. Nature. 1997;386(6626):671-4.

Risau W, Flamme I. Vasculogenesis. Annu Rev Cell Dev Biol. 1995;11:73-91.

Rodgers LS, Lalani S, Runyan RB, Camenisch TD. Differential growth and multicellular villi direct proepicardial translocation to the developing mouse heart. Dev Dyn. 2008;237(1):145-52.

Rongish BJ, Hinchman G, Doty MK, Baldwin HS, Tomanek RJ. Relationship of the extracellular matrix to coronary neovascularization during development. J Mol Cell Cardiol. 1996;28(10):2203-15.

Semenza GL. Regulation of tissue perfusion in mammals by hypoxia-inducible factor 1. Exp Physiol. 2007;92(6):988-91.

Smart N, Dube KN, Riley PR. Coronary vessel development and insight towards neovascular therapy. Int J Exp Pathol. 2009;90(3):262-83.

Sucov HM, Gu Y, Thomas S, Li P, Pashmforoush M. Epicardial control of myocardial proliferation and morphogenesis. Pediatr Cardiol. 2009;30(5):617-25.

Takahashi K, Yamanaka S. Induction of pluripotent stem cells from mouse embryonic and adult fibroblast cultures by defined factors. Cell. 2006;126(4):663-76. 
Tomanek RJ. Formation of the coronary vasculature during development. Angiogenesis. 2005;8(3):273-84.

Tomanek RJ, Ratajska A, Kitten GT, Yue X, Sandra A. Vascular endothelial growth factor expression coincides with coronary vasculogenesis and angiogenesis. Dev Dyn. 1999;215(1):54-61.

Tomanek RJ, Sandra A, Zheng W, Brock T, Bjercke RJ, Holifield JS. Vascular endothelial growth factor and basic fibroblast growth factor differentially modulate early postnatal coronary angiogenesis. Circ Res. 2001;88(11):1135-41.

Tomanek RJ, Zheng W. Role of growth factors in coronary morphogenesis. Tex Heart Inst J. 2002;29(4):250-4.

Urbich C, Dimmeler S. Endothelial progenitor cells: characterization and role in vascular biology. Circ Res. 2004;95(4):343-53.

van Tuyn J, Atsma DE, Winter EM, van der Velde-van Dijke I, Pijnappels DA, Bax NA et al. Epicardial cells of human adults can undergo an epithelial-to-mesenchymal transition and obtain characteristics of smooth muscle cells in vitro. Stem Cells. 2007;25(2):271-8.

Viragh S, Challice CE. The origin of the epicardium and the embryonic myocardial circulation in the mouse. Anat Rec. 1981;201(1):157-68.

Viragh S, Gittenberger-de Groot AC, Poelmann RE, Kalman F. Early development of quail heart epicardium and associated vascular and glandular structures. Anat Embryol (Berl). 1993;188(4):381-93.

Wada AM, Smith TK, Osler ME, Reese DE, Bader DM. Epicardial/Mesothelial cell line retains vasculogenic potential of embryonic epicardium. Circ Res. 2003;92(5):525-31.

Watanabe N, Nakagawa M, Hanato T, Takeuchi Y, Hara M, Yoshida T et al. In vitro model for mouse coronary vasculogenesis. Anat Rec A Discov Mol Cell Evol Biol. 2006;288(7):714-22.

Wessels A, Perez-Pomares JM. The epicardium and epicardially derived cells (EPDCs) as cardiac stem cells. Anat Rec A Discov Mol Cell Evol Biol. 2004;276(1):43-57. 
Winter EM, Gittenberger-de Groot AC. Epicardium-derived cells in cardiogenesis and cardiac regeneration. Cell Mol Life Sci. 2007;64(6):692-703.

Xavier-Neto J, Shapiro MD, Houghton L, Rosenthal N. Sequential programs of retinoic acid synthesis in the myocardial and epicardial layers of the developing avian heart. Dev Biol. 2000;219(1):129-41.

Zhou B, Ma Q, Rajagopal S, Wu SM, Domian I, Rivera-Feliciano J et al. Epicardial progenitors contribute to the cardiomyocyte lineage in the developing heart. Nature. 2008;454(7200):109-13. 